Portland State University

PDXScholar

6-28-2005

\title{
Ambivalent Landscapes: An Historical Geography of Recreation and Tourism on Mount Hood, Oregon
}

Ryan Franklin Mitchell

Portland State University

Follow this and additional works at: https://pdxscholar.library.pdx.edu/open_access_etds

Part of the Human Geography Commons, and the Physical and Environmental Geography Commons Let us know how access to this document benefits you.

\section{Recommended Citation}

Mitchell, Ryan Franklin, "Ambivalent Landscapes: An Historical Geography of Recreation and Tourism on Mount Hood, Oregon" (2005). Dissertations and Theses. Paper 2227.

https://doi.org/10.15760/etd.2224

This Thesis is brought to you for free and open access. It has been accepted for inclusion in Dissertations and Theses by an authorized administrator of PDXScholar. Please contact us if we can make this document more accessible: pdxscholar@pdx.edu. 


\section{THESIS APPROVAL}

The abstract and thesis of Ryan Franklin Mitchell for the Master of Science in

Geography were presented June 28, 2005, and accepted by the thesis committee and the department.

COMMITTEE APPROVALS:

Barbara Brower, Chair

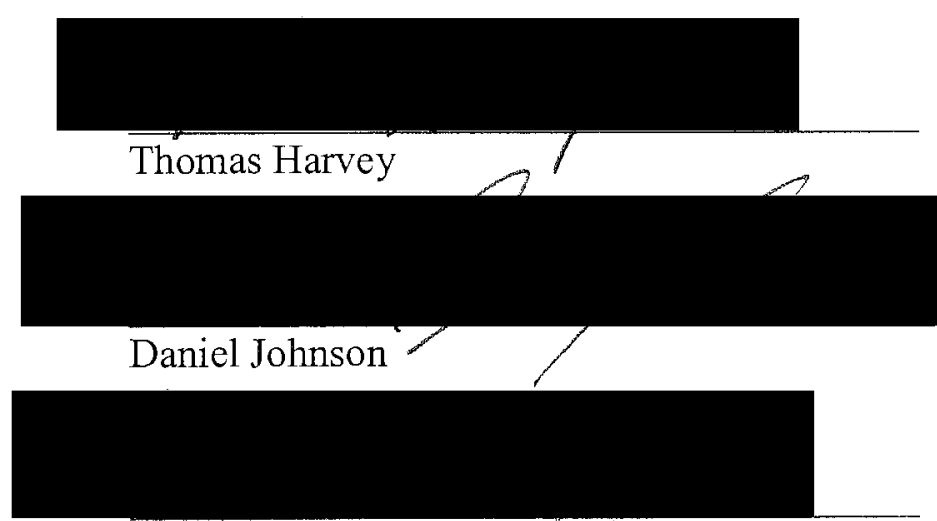

William Lang

Representative of the Office of Graduate Studies

DEPARTMENT APPROVAL:

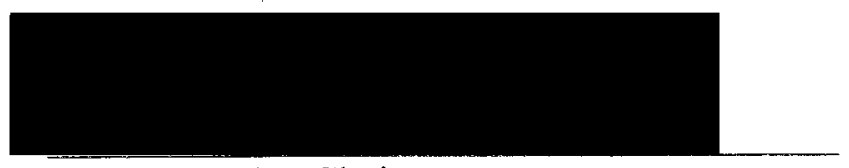

Martha Works, Chair

Department of Geography 


\begin{abstract}
An abstract of the thesis of Ryan Franklin Mitchell for the Master of Science in Geography presented June 28, 2005.

Title: Ambivalent Landscapes: An Historical Geography of Recreation and Tourism on Mount Hood, Oregon.
\end{abstract}

Mount Hood is an Oregon icon. The mountain has as long and rich a history of recreation and tourism as almost any other place in the American West. But contemporary landscapes on Mount Hood reveal a recreation and tourism industry that has struggled to assert itself, and a distinct geographic divide is evident in the manner in which tourism has been developed. Why? In this study I chronicle the historical geography of recreation and tourism on Mount Hood. I examine the evolution of its character and pattern, and the ways in which various communities have used it to invest meaning in the places they call home. Despite the efforts of early boosters, Mount Hood has never been home to an elite destination resort like Aspen, Sun Valley, or Vail. Instead, modest recreation developed alongside timber and agriculture, and today the area is primarily a regional attraction. Unlike destinations with national and international clienteles that play a significant role in shaping lives and landscapes, local and regional interests are the primary drivers of recreation and tourism on Mount Hood. Communities on the mountain have incorporated the industry into their lives and landscapes to varying degrees. Mount Hood is also inextricably tied to Portland, and as an integral part of the city's history and identity, reflects its 
residents' tastes, values, and priorities. This combination of local and metropolitan interests has left an imprint on Mount Hood that reflects tensions and contradictions that define Oregon in the early twenty-first century: past vs. future, old vs. new economies, urban vs. rural inclinations, progress vs. status quo, and upscale vs. modest tastes. Spatially, temporally, and psychologically, Mount Hood straddles the divide between two visions: a service-based economy in the Willamette Valley, heavily dependent on technology, and a traditional, resource-based economy in much of the rest of the state. 


\author{
AMBIVALENT LANDSCAPES: \\ AN HISTORICAL GEOGRAPHY OF \\ RECREATION AND TOURISM ON \\ MOUNT HOOD, OREGON
}

\author{
by \\ RYAN FRANKLIN MITCHELL
}

A thesis submitted in partial fulfillment of the requirements for the degree of

MASTER OF SCIENCE

in

GEOGRAPHY

Portland State University

2005 
For Mary 


\section{Table of Contents}

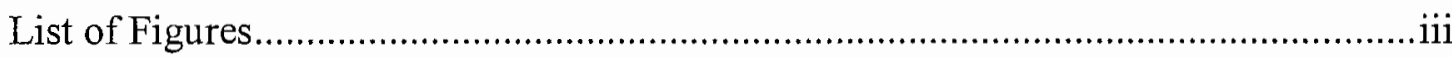

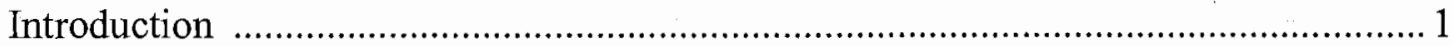

I. "Place-stories": Context, influences, and approach …………....................... 7

II. Ambivalent landscapes: The contemporary scene .............................................. 13

The north side: Parkdale and the Upper Hood River Valley .................... 16

The south side: Government Camp …................................................... 22

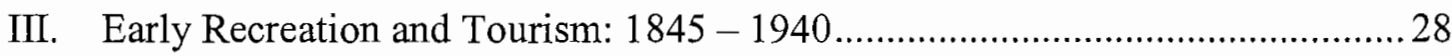

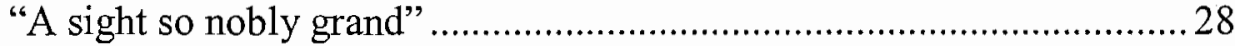

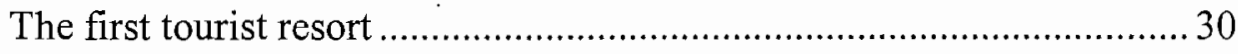

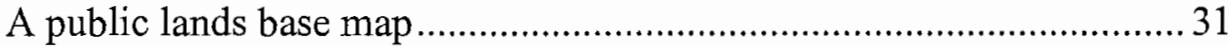

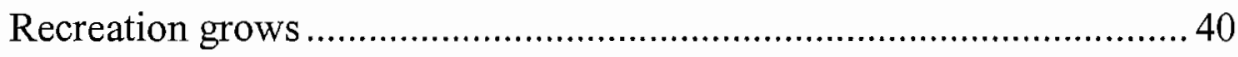

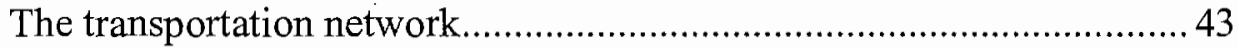

Mount Hood gains new fame …............................................................. 49

IV. Recreation and Tourism after World War II: 1940 - $1996 \ldots \ldots \ldots \ldots \ldots \ldots \ldots \ldots \ldots \ldots \ldots \ldots . . . .66$

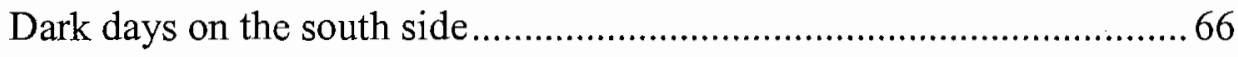

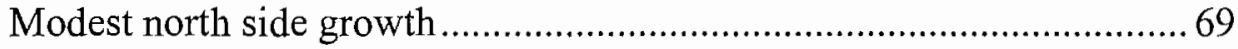

A new north side ski area .................................................................... 73

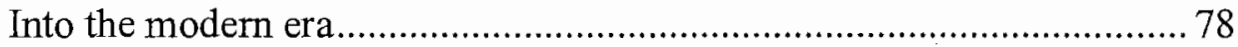

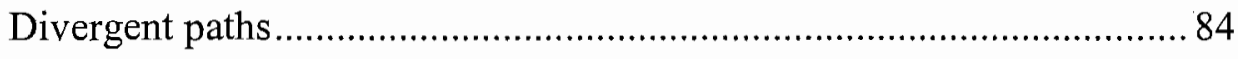

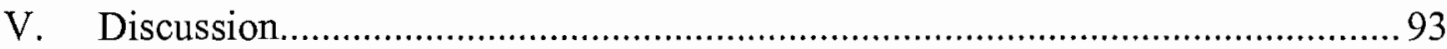

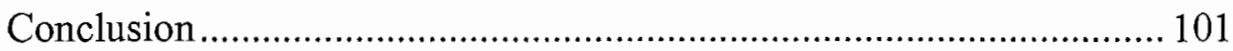

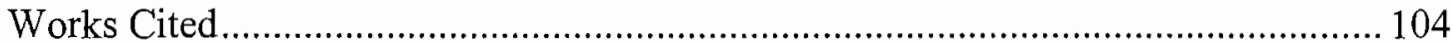

Appendix A: Timeline of Recreation and Tourism Development on

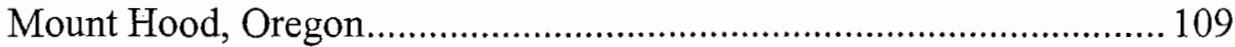




\section{List of Figures}

Figure 1. Mount Hood-Portland region ............................................................... 14

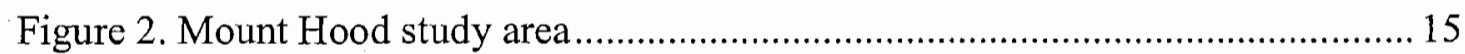

Figure 3. North side of Mount Hood ..................................................................... 17

Figure 4. Mount Hood Railroad and Hutson Museum, Parkdale ................................. 20

Figure 5. Elliot Glacier Public House, Parkdale .......................................................... 20

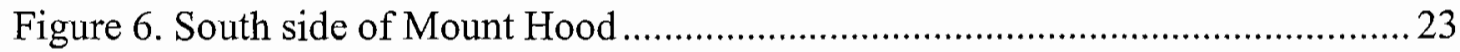

Figure 7. Charlie's Mountain View Restaurant, Government Camp ........................... 24

Figure 8. Summit Ski Area, Government Camp .................................................... 26 


\section{Introduction}

Mount Hood is an Oregon icon. Almost any promotional or tourism literature for Portland or Oregon features a glossy photo of the mountain. Travel guidebooks and lifestyle magazines invariably describe Oregonians as a people with an affinity for the outdoors. As a beacon for much of the state, the mountain beckons many of these recreationists to come play on its slopes. The mountain is widely considered to be the second most climbed mountain in the world (after Mount Fuji in Japan); more than 10,000 climbers summit Mount Hood each year. The Mount Hood National Forest receives an estimated four million visitors annually (USDA Forest Service 2004). The mountain's five ski areas register nearly $3 / 4$ million skier days on average each year (PNSAA 2004). " "Portlanders give Mount Hood a reverence that borders on devotion. Even though residents of two states share in the glory of its presence, Mount Hood is still regarded as their own by prideful Portlanders. They see it there-not even in their own county-as a part of the city, as much so as those hills on which Portland is built" (McNeil 1990:12).

Mount Hood also has as long and rich a history of recreation as almost any other place in the West. The mountain was first climbed in 1857. Cloud Cap Inn, the mountain's first resort retreat, was built on Cooper Spur in 1889. The Mazamas, one

\footnotetext{
1 The Forest Service's National Visitor Use Monitoring program defines a national forest visit as the entry of one person upon a national forest to participate in recreation activities for an unspecified period of time. A national forest visit can be composed of multiple site visits. The National Ski Areas Association defines 'skier days' as one person visiting a ski area for all or any part of a day or night for the purpose of skiing.
} 
of the country's oldest mountaineering clubs, was founded on its summit in 1894 . Timberline Lodge, the Works Progress Administration's architectural gem, was built in 1937. The world's second chairlift was installed at Timberline Ski Area in 1939, and for a short period Mount Hood was an epicenter of winter sports in North America.

Several generations of skiers, hikers, and climbers who grew up on Mount Hood share and revel in this history. Tourism marketers evoke it on brochures, posters, and Web sites. The Mount Hood Museum and Cultural Center in Government Camp opened in 2002 largely to commemorate the recreation and tourism heritage of the mountain. Recent efforts to place the Tilly Jane trail on the northeast flank of the mountain on the National Register of Historic Places also reflect an appreciation of the mountain's recreation past. A contemporary marketing campaign for the Mount Hood Territory (by Clackamas County) evokes the mountain's history on posters with period illustrations featuring Timberline Lodge and other scenes of post-war-era tourists.

Despite this history and its contemporary popularity, landscapes on Mount Hood today reveal a recreation and tourism industry that has struggled to assert itself.

The sophisticated, upscale character that has evolved at destination resorts around the West has never come to dominate the landscapes on and around Mt Hood.

Mount Hood has never been a rich man's refuge. For decades it has been a blue-collar place, where the work of logging went side by side with the pleasure of pitching a tent on a lake. No Aspen or Vail, Colo., sprouted on Mount Hood. Instead, there are taverns, restaurants, and stores, the kinds of places you need to get by, not ahead (Sleeth 1996). 
Even in areas where tourism and recreation dominate the economy, the character of the businesses and infrastructure is decidedly humble. Government Camp has been variously described as blighted, down-at-the-heels, and a story of missed opportunity, and many businesses still appear to be just getting by.

In addition, a distinct geographic divide in the manner in which recreation has developed is evident in the contemporary scene. On the south side of the mountain, recreation dominates the Highway 26 corridor between Sandy and Government Camp known as Hoodland. In contrast, signs of recreation and tourism are much more subtle in the Upper Hood River Valley on the mountain's northeast side—a casual observer may not notice some of them at all.

In this study, I seek to explain why contemporary landscapes on Mount Hood look as they do. I chronicle the development of recreation and tourism on Mount Hood using a conceptual framework of landscape, location, and place that is rooted in the discipline of historical geography. I examine the evolution of the character and pattern of recreation development and the ways in which various communities have used it to invest meaning in the places they call home.

Despite the efforts of early tourism boosters, Mount Hood has never become an elite destination resort such as Aspen or Vail or Sun Valley. Instead modest recreation developed, and today the area is primarily a regional attraction. While outside forces often shape development at the elite resorts, local and regional interests have had more influence on development on Mount Hood. Communities on the mountain have incorporated recreation and tourism into their lives and landscapes to varying degrees, 
according to the visions they have for themselves. At the same time Mount Hood is also inextricably tied to Portland, and is an integral part of the city's identity. The mountain and its environs have been a playground for Portland residents for a century and a half. As a result, the landscapes on Mount Hood reflect the tastes, values, and priorities of the city's residents as much as, if not more than, those of local communities.

Mount Hood is many things to many people. "Cultural landscapes of the Mountainous West often highlight the sharply divided visions of what the region should be" (Wyckoff and Dilsaver 1995:11). Most debates over development on the mountain have turned on the nature and degree of development of recreation and conflicting identities rooted in recreation-based economies and more traditional, resource- and agriculture-based economies. ${ }^{2}$

My emphasis in this study is on developed recreation, specifically the built environment. I focus primarily on buildings, infrastructure, and other recreationoriented structures. I am less interested in dispersed recreation such as wilderness or hiking trails or even the in-between landscapes of campgrounds and picnic areas.

\footnotetext{
${ }^{2}$ There have been several proposals for recreation and tourism development and discussions of public lands management on Mount Hood in the last few years. The controversial expansion of the Cooper Spur ski area and development of a destination resort with a golf course, retail center, and condominiums is perhaps the most highly publicized of these proposals. But a number of other plans that have surfaced recently would have significant implications for tourism and recreation development as well as management of public lands on Mount Hood. Partially in response to the Cooper Spur proposal, the Tilly Jane Historic Trail has been nominated for listing on the National Register of Historic Places. In spring 2004 Senator Ron Wyden proposed adding 164,000 acres of wilderness on the Mount Hood National Forest. Another organization has revived proposals for a Mount Hood National Park. In the summer of 2003, Oregon Congressmen Earl Blumenauer and Greg Walden organized a summit to bring together the various parties with interests in development on Mount Hood to begin a dialogue for a comprehensive, inclusive approach to future development on Mount Hood.
} 
Because mountain resort developments tend to revolve around skiing and much of the mountain's recreation history involves skiing, my story of Mount Hood is told largely in the context of this one winter sport. I consider other activities, particularly dispersed recreation, to the extent that they were involved in establishing and using general patterns and material culture of recreation and tourism in the landscapes. Additionally, I consider the role of timber and agriculture to the extent that they have been incorporated into tourism or used as an alternative with which to resist recreation development.

I am also interested primarily in development "on the mountain." By this I mean the area in which the historical recreation focus has been on Mount Hood and where a mountain-oriented resort is likeliest to be built. I exclude Hood River because I believe the tourism development there is tied as much, if not more, to the Columbia River than to Mount Hood. Similarly, on the south side, I exclude Sandy and most of the Hoodland corridor because they are more characteristic of gateway communities and access corridors than destination resorts. For this reason, my study concentrates primarily on the Upper Hood River Valley and Government Camp.

I begin in Chapter I with a brief review of other studies that provide context and a departure point for this project. I also discuss a basic conceptual framework for considering the historical geography of recreation and tourism on Mount Hood, and describe my approach to the project. In Chapter II, I sketch the contemporary scene on the mountain, drawing a contrast in the manner in which recreation has been developed on the north and south sides and describing the character of this 
development. In Chapter III, I recount the early history of Mount Hood recreation and tourism. I begin with the crossing of Sam Barlow in 1845, but focus more closely on the period beginning with the construction of Cloud Cap Inn in 1889, and end at the dawn of World War II in 1940. I trace the development of the basic framework (pattern, distribution, character, and nature) of recreation and tourism on Mount Hood in the larger context of the establishment of national public lands and recreation policy. In Chapter IV, I discuss recreation and tourism after World War II, from the relatively quiet post-war years and the decline of Mount Hood's national eminence in winter recreation with the surge of resort development in the 1960s and ' 70 s, and the south side's concomitant slide into blighted tourist destination. This chapter considers the continuing dynamic between local and regional interests as seen through the development of the Mount Hood Meadows ski area. I look at renewal efforts on the south side and attempts to reconcile tourism with local identity on the north side. I end in the late 1990s, prior to Mount Hood Meadows' proposal for a destination resort at Cooper Spur on the north side of the mountain. I conclude in Chapter V with a discussion of the ways in which local and regional interests have influenced the pattern and character of recreation and tourism development on Mount Hood. 


\section{I}

\section{"Place-stories": Context, influences, and approach}

"Good environmental history and good historical geography could well be regarded as a series of place-stories" (Williams 1994: 15). There is tremendous potential in these stories to increase the understanding and appreciation of the landscapes in which the human drama unfolds. This study takes a narrative approach that draws on a conceptual framework rooted in the discipline of historical geography. Donald Meinig's framework of spatial systems, social geographies, and cultural landscapes is a useful lens with which to capture the ways in which places change with time (1972, 1978). Wyckoff adopts this framework, using themes of location, place, and landscape to produce a geographical synthesis of the state of Colorado. Location considers how and why settlement occurs where it does, and on "flows and movements within and between regions." Place focuses on the social geographies of an area. It emphasizes the ways in which "distinctive social and cultural groups invest meaning ... into their local neighborhoods and communities" and how they "define themselves socially and spatially." Landscape, or cultural landscape, is a concept discussed at great length by many people within and outside of the discipline of geography. It refers to "the signatures people leave upon the visible scene and what those imprints can tell us about a culture and its relation to the environment. ... In this sense, landscape is material culture, a concrete expression of habits, technology, and the distributions of power and authority within society" (Wyckoff 1999:6). 
Local economies in much of the American West have historically relied on resource extraction. But in recent years, shifting demographics, concern over environmental degradation, and declining resource extraction have led many communities in the region to turn to service-based economies that capitalize on the region's scenery and other natural amenities. This transition from primary to tertiary economies is apparent throughout the country and in other parts of the world, but it is one of the defining elements of the American West today (Riebsame and Robb 1997).

This trend is part of the most recent stage of recreation and tourism's evolution in the West, which dates to the earliest settlement of the region. Earl Pomeroy chronicled the early stages of tourism development in the region and describes the social changes and technological advances that prompted its growth and shapes the industry today.

Each decade saw more families with leisure time and money to spend in it; the West as well as the East was becoming urbanized, and even its more modest towns spawned their vacation spots. Gradually this mass market became more important to the tourist industry as a whole than the patronage of the elite. The great profits in the Western tourist and vacation industry came not from serving squab to the few but from selling gasoline, hamburger sandwiches, and postcards to the many, who lived in Los Angeles and Seattle as well as in Cincinnati and Boston (Pomeroy 1957: 113).

Pomeroy also identifies the development in these early stages of a number of the industry's trends that have drawn recent criticism. The marginalization and novelization of native populations and other minorities, the industrialization of tourism, the creation of mythical imagery for the purpose of selling tourism, and the transformation of communities have roots that go back a century and a half. 
Modern chambers of commerce across the West consider tourism a panacea for ailing rural economies, and some scholars have identified benefits of tourism. Economist Thomas Michael Power (1996) challenges common criticisms of tourism by considering it in the context of its alternatives. Power rejects the belief that the service-based industry is an illegitimate or less viable alternative to extractive industries, and maintains that when pursued carefully and thoughtfully, tourism is economically and environmentally sustainable.

Although one could argue that tourism is just another boom that will ultimately leave our communities bust, the length of tourism's cycle is much longer than timber or mining or agriculture's. Most leading tourist destinations in the United States have enjoyed expanding or at least stable markets for a long time.... While acknowledging that tourism has an environmental impact, it is important to ask, Compared to what? Backpackers and hunters may be so numerous that they start to damage the land and wildlife in a particular area, but they will probably never have as disruptive an impact as clear-cutting millions of acres of forest has had (Power 1996: 215-221).

Echoing many government and business proponents of tourism, he cites benefits of economic diversification, decentralization of economic activity, positive multiplier effects, infusion of investment, and increased value placed on environmental protection.

Many scholars, however, have pointed out the industry's negative consequences. Environmental historian Hal Rothman characterizes tourism as a devil's bargain in which local residents fail to realize the full benefits of development and instead lose their autonomy, identity, and even their homes as new money and power come in with large-scale development. Tourism is a modern form of 
colonialism in which outside interests (often shareholders) hold the power and control the destinies of local residents. This characterization suggests that the New West's economy and landscapes are not so different from those of the Old West that were shaped by grazing, timber, and mining interests (Coleman 2004). In this post-modern form of colonialism, consumption of image and lifestyle by outsiders replaces resource extraction (Rothman 1996, 1998a, 1998b).

In this paradigm, outside interests play a significant role in shaping local landscapes. Many destinations have been carefully crafted to reflect the expectations of visitors while perpetuating many of the West's myths. The "colorful, exotic, and mythic aspects" of a town's past are used "to turn [contemporary] mountain towns into European alpine villages, Victorian mining towns, the Wild West, or some mixture of each" (Coleman 2004). Most studies of tourist areas that fit the post-modern colonial model focus on the large, highly developed, and nationally (or internationally) renowned destinations: Aspen, Vail, Sun Valley, and others. These are the areas whose identities are largely shaped by and reflect the expectations of national and international constituencies.

Landscapes and identities in these elite resorts are likely to develop differently from those in smaller, less well known areas. In 1996 Forbes magazine described a noteworthy trend in the ski industry, precipitated by consolidation of ski resorts among a few large companies, in which ski areas are being forced to "go big or go home." This take-off on the lingo of gravity-defying skiers and snowboarders strikes at the core of ski area operators' new imperative: appeal to skiers either with large resorts 
that offer an amenity-rich, Disney-like vacation experience or with convenient, affordable local hills within easy day-trip striking distance of population centers. The latter "regional areas thrive by understanding their majority clientele--curious beginners and young cash-strapped diehards. This is basic skiing, no frills. No hotel fitness clubs or 'gourmet' restaurants" (Lane 1996).

Implicit in this article is that the two models of ski area development are likely to have markedly different impacts on landscapes. Elite destination resorts look much different than regional attractions where the majority of visitors return home to eat, sleep, and shop. These local and regional areas are more likely to reflect some combination of the needs, priorities, and tastes of local communities and the population center they serve than those of a national or international clientele.

Urban centers often lay claim to these regional recreation areas, and "city residents ... mold rural resource communities and districts in their own image around the goal of recreation," resulting in conflict between rural and urban interests (Abbott 2000: 80). These areas are often the meeting grounds of contrasting worldviews. They are an economic and social frontier where Old West and New West collide. Inherent in this intersection is a series of related tensions and contradictions--tensions and contradictions that Oregon struggles to reconcile. The Columbia River Gorge Scenic Area, under the gaze of Mount Hood and at the transition between urban and rural Oregon, is symbolic of attempts to reconcile these tensions at a broader regional scale (Abbott 2003, Abbot, Adler, and Abbott 1997). Similarly, recreation and tourism development on Mount Hood represent Oregon and the West's effort to balance past 
and future, old and new economies, urban and rural inclinations, progress and status quo.

Mount Hood has been the subject of several popular histories. Newspaperman Fred McNeil's Wy'East: The Mountain, first published in 1937 (the 1990 reprint is cited in this study), chronicles many of the events and personalities of early recreation on Mount Hood. It is a minor regional classic and a primary source for several subsequent works, including Jack Grauer's Mount Hood: A Complete History, Jean Arthur's sentimental history of Timberline and skiing in general on Mount Hood, and Don and Roberta Lowe's photographic "portrait" of the mountain (Arthur 1998; Grauer 1975; Lowe 1975). There have also been a number of popular and academic histories of Timberline Lodge (Griffin and Munro 1978; Griffith n.d.; Rose 1986; Weir 1977).

These works relate anecdotes, tales, and facts about first feats, colorful personalities, and daring skiing and mountaineering accomplishments that help to bond the recreation culture that is centered on the mountain. But the history of recreation and tourism development on Mount Hood can also reveal much more. Consideration of the complementary concepts of location, place, and landscape yields common themes that help gain a sense of the broader meaning of one of Oregon's most recognizable symbols. 
Divided landscapes: the contemporary scene

At 11,239 feet, Mount Hood is Oregon's tallest mountain. The summit is just 50 miles east of Portland and the two million people of the metropolitan region. The Mount Hood National Forest is one of fourteen national forests in the country within fifty miles of a metropolitan area of greater than one million people that have been classified as urban forests. The mountain stands sentinel over the Columbia River, seemingly ready, as in Native American legend, to fight with his brother Mount Adams across the river for the heart of a beautiful young maiden. Wy'east, as he is known by Native Americans, sits at the crest of the Cascade Range, approximately midway between the range's northern end in southern British Columbia and its southern terminus in northern California, straddling the divide between the soggy comer of the country that many people associate with the Pacific Northwest and the arid interior to the east.

As one travels the Mount Hood Loop Highway from Portland through Government Camp around to the east side of the mountain, changes in the physical landscape are evident. On a winter or spring day, even the most casual observer feels his or her mood elevate as the clouds of the west side give way to clear skies on the east. There is a feeling of greater openness, a hint that the traveler is nearer-while not quite there--the wide open and arid landscapes that characterize the interior American West. 


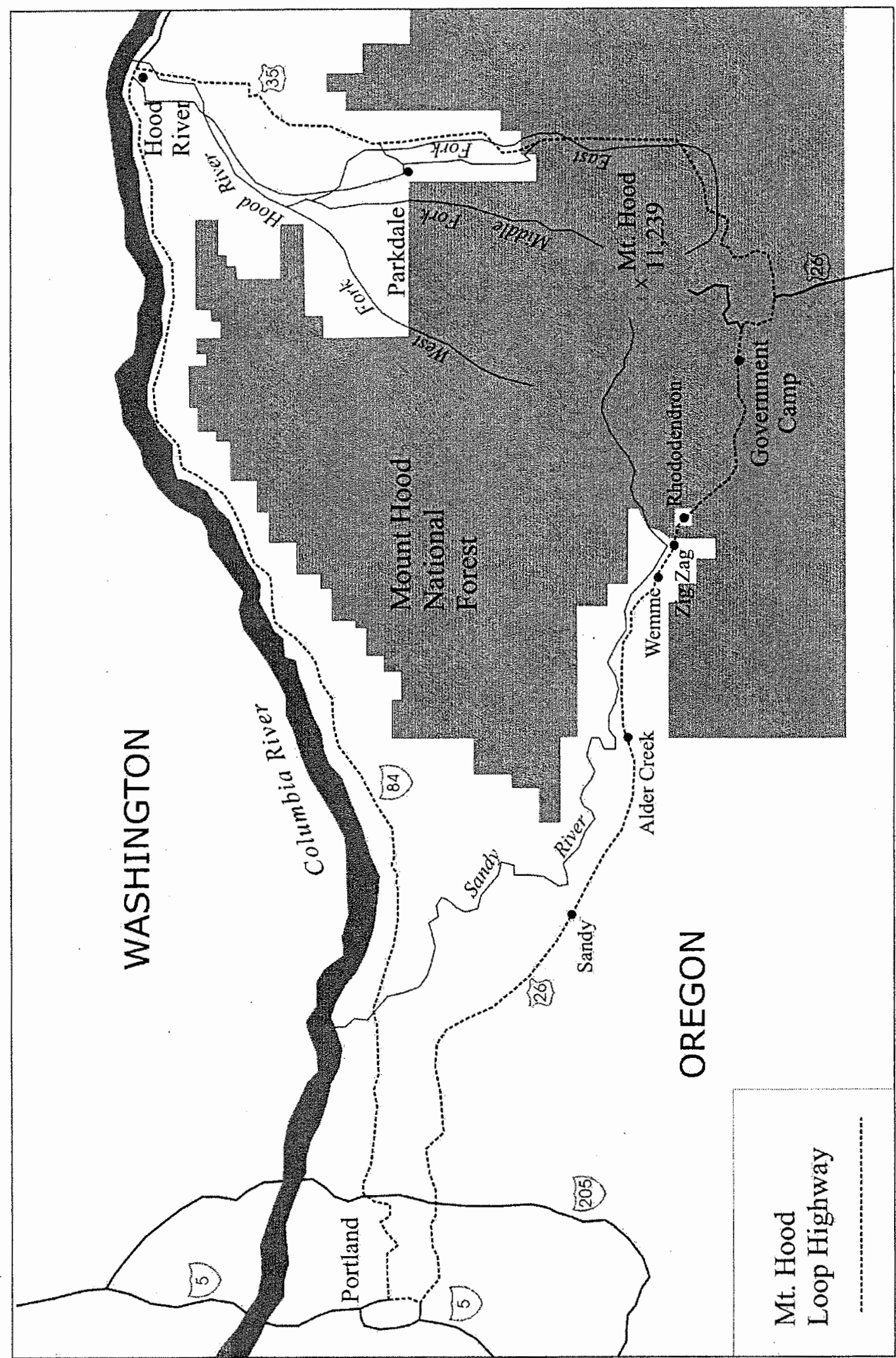

Figure 1. Mount Hood-Portland region 


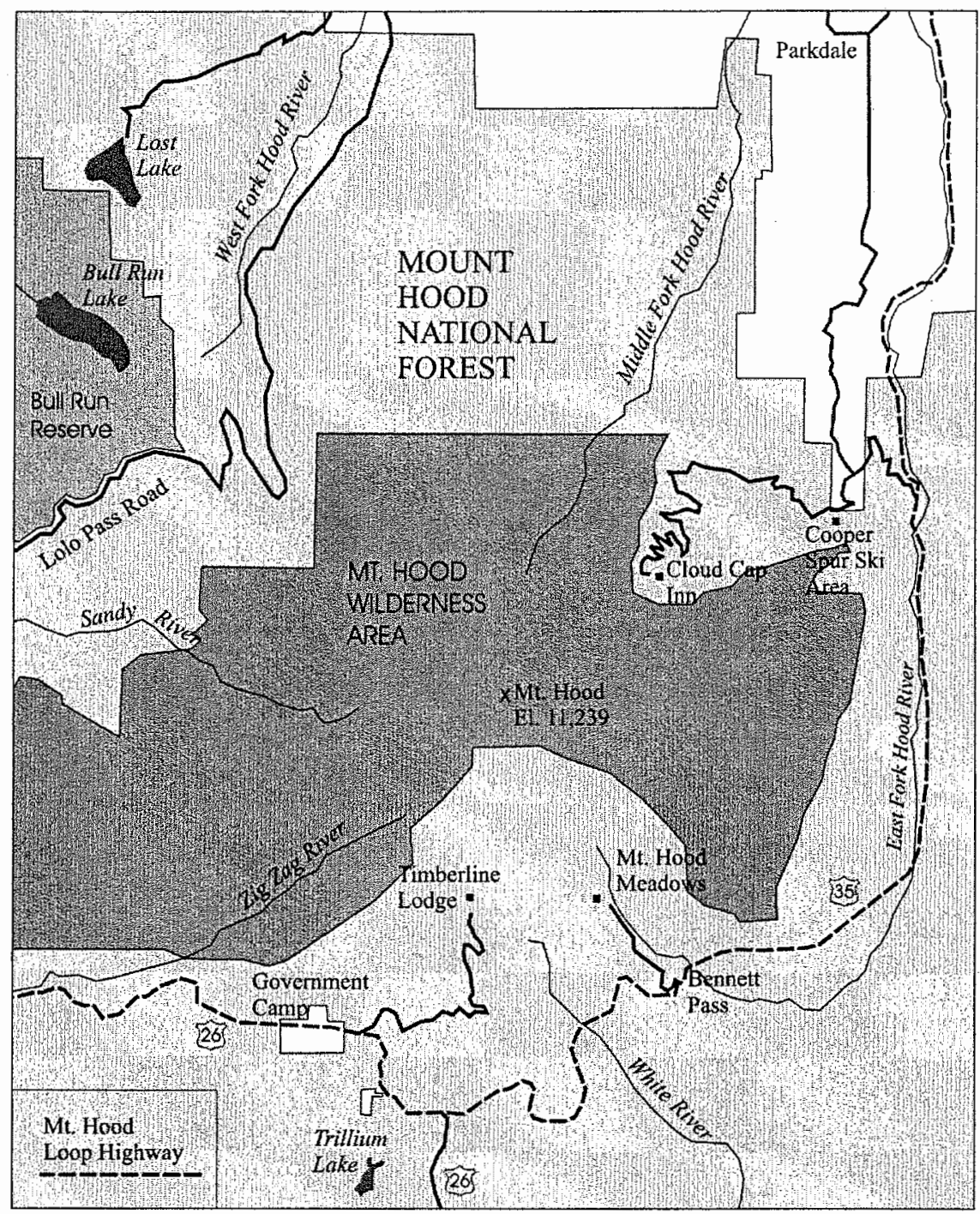

Figure 2. Mount Hood study area

From Sandy the highway passes through a dark, some would say dreary, forest.

It gains elevation to reach Government Camp and continues farther to Barlow Pass and the high point of the loop highway, Bennett Pass. The temperate western hemlock and western red cedar forests of the west side - now largely replaced by Douglas-fir stands as a result of widespread and frequent disturbance-yield to forests of Pacific silver fir and mountain hemlock, indicating that the traveler is getting closer to the 
subalpine vegetation zone. Continuing around the loop highway, the presence of subalpine fir and Englemann spruce, typical of interior subalpine forests, suggests to the traveler that he or she is on the drier, northeast side that is the rainshadow of Mount Hood. Dropping down into the valley of the East Fork Hood River, stands of lodgepole pine line the highway. Ponderosa pine stands in the Hood River Valley are an indication of the drier lands that lie just to the east.

Differences in topography are also evident as one travels around the mountain. On the south side, a broad, gently sloping apron of volcanic debris fans out from Crater Rock down to Government Camp. Significantly, this accessible topography contrasts with that on much of the rest of the mountain. It is not necessary to travel far beyond Government Camp to see these differences. A few miles to the east, between Barlow and Bennett Passes, the White River flows from a glacier of the same name to periodically wash out the bridge on Highway 35 . Heavily crevassed glaciers, steep slopes, and deep valleys characterize the mountain's other aspects. These differences in physical geography influence, at least in part, the cultural geographic divide on Mount Hood.

\section{The north side: Parkdale and the Upper Hood River Valley}

The abundant sunshine in the mountain's rain shadow, along with fertile volcanic soils and cool nights, have made the Hood River Valley one of the premier orchard regions in the world. Agriculture has dominated the valley for decades and, despite pressure from foreign growers, it is still the most evident land use. Approximately 6,400 acres 
of orchards produce 192,000 bins of fruit-mostly pears-in the Upper Hood River Valley each year (UHRV Action Team 1997).

The Upper Hood River Valley begins roughly ten miles south of Hood River at an elevation of approximately 1,000 feet, and includes areas drained by the west, middle, and east forks of the Hood River. Its upper extent is commonly considered to

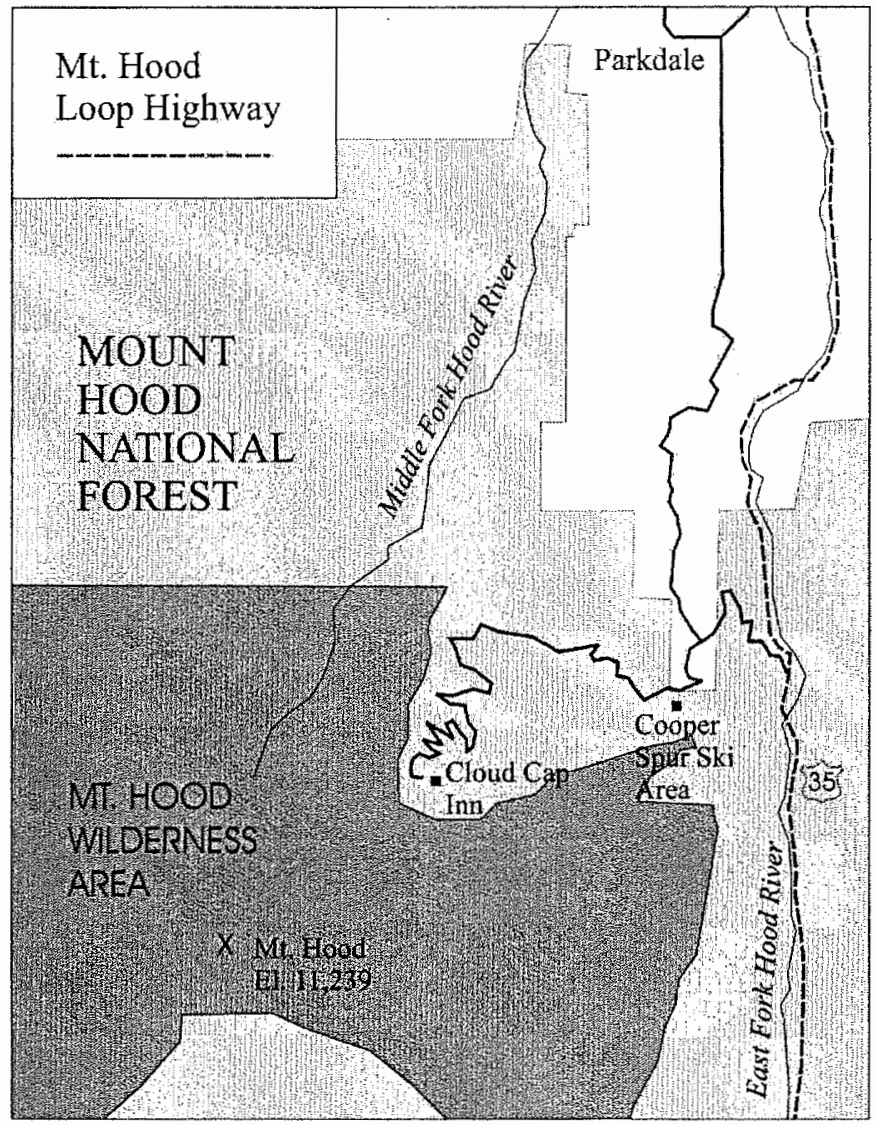

Figure 3. North side of Mount Hood

be the Mount Hood National Forest boundary, but given its significance in valley life, much of the national forest can legitimately be included. The unincorporated communities of Parkdale, Mount Hood, and Dee are the main population centers of the 
Upper Valley. With 266 people, Parkdale, at the heart of the upper valley, is the largest of these (UHRV Action Team 1997).

As they do nearly everywhere else in the valley, stacks of fruit harvest bins declare the primacy of orchards in Parkdale. Stacked ten high in empty lots next to and across the street from residences, the crates indicate the degree to which the industry is intertwined with the lives of the residents. Businesses along the main road through town back up directly to orchards. A large Diamond Fruit Growers facility, Valley Agricultural Services, and the local grange on the periphery of town are further testimony to the primary livelihood in the Upper Valley.

The presence of the timber industry is also evident in Parkdale. Visible from Baseline Road in the center of the small town, clearcuts on the hillsides flanking the valley are evidence of the industry's not-too-distant past. Testimony that large-scale timber harvests are perhaps relegated to the valley's past is the fact that the only tangible clues in town are found the Hutson Museum on the corner of Baseline and Clear Creek Roads. The small amphitheater on the museum grounds uses for its stage a four-foot-diameter tree stump. Not far away, next to a picnic shelter, sits an old log truck with several large trees.

The Hutson Museum and the adjacent southern terminus of the Mount Hood Railroad are the center of the modest tourism activity in Parkdale. The structure has historic character despite being built only ten years ago. There are picnic tables, a shelter, a large grassy area, and a small amphitheater on the site--all with a stunning view of Mount Hood. The railroad runs up the valley through the orchards from Hood 
River during the summer, and activity in town pulses with the train's arrival and departure. The orientation of this focal area of tourism toward the mountain, both in aspect and its position in town, is not insignificant. One gets the feeling that the mountain will continue to be critical to Parkdale's future, whatever that may be.

Strolling along the two blocks of Baseline Road that are the town's tourism "district," one finds many of the establishments (if just one of each) that are the mainstays of today's tourist town: a brewpub, bed and breakfast, antique shop, deli, ice cream and espresso stand, and artisans' market. An indication of the scale of the tourism sector in Parkdale, a sign that greets trains passengers as they cross Baseline from the north proclaims the church's stained glass windows, the auto repair shop, the appliance store, the library, and the post office as other worthy attractions. The condition of the commercial buildings is an indication that tourism development has been only a token effort here. Several buildings are in need of minor structural repairs and a fresh coat of paint. Upkeep and maintenance in general do not meet the standards of a dedicated tourist town.

Some of the retail stores that are common in tourist towns are conspicuously absent from Parkdale. It does not have Hood River's windsurfing shops, nor does it have any ski shops, bike shops, or bookstores. Perhaps most telling is the lack of the tee-shirt shops that seem to proliferate in tourist destinations. The presence of the Oregon Child Development Coalition's Migrant and Seasonal Head Start office on the main street through town is another indication that this is no Aspen or Vail. 
A few miles south of Parkdale, just beyond the national forest boundary, lies the Cooper Spur Ski Area, a small, family area that has served the valley for decades. Ten miles up Cloud Cap Road from the Cooper Spur Ski Area, at almost 6,000 feet, is the Cloud Cap-Tilly Jane Historic Area. In addition to Cloud Cap Inn, the Tilly Jane Guard House, Tilly Jane Ski Cabin, and several other structures that date from the early twentieth century are testimony to the Upper Valley's long recreation history.

Seventeen miles south of Parkdale on Highway 35 is Mount Hood Meadows. This ski area is Mount Hood's largest and Oregon's second largest. It has been described as the biggest day area in the country (Giordano 2004). Although the ski area sits on the southeast flank of the mountain, it is located in the headwaters of the East Branch of the Hood River and is bound to the upper valley.

Without the overwhelming presence of tourism and its trappings, Parkdale has many qualities of a small country town. When the train is not in town, it is peaceful and quiet. Children ride around on their bikes unattended. Unleashed dogs wander aimlessly and harmlessly, their barking occasionally heard through town. Local rural color is evident from time to time when a four-wheeler or unmuffled pickup truck cruises down a side street. A community center with a play area and ball field is prominent across from the museum. One local business proclaims on its sign, "Hometown Business, Hometown Pride." 


\section{The south side: Government Camp}

After leaving Sandy heading east, Highway 26 passes through several small, unincorporated hamlets before climbing Laurel Hill to Government Camp. The landscapes in this corridor are similar to those of access roads to any number of resort areas. Businesses consist primarily of gas stations, grocery stores, fast food restaurants, and motels. While a number of establishments appear to be thriving, an equal number or more look like the kinds of places that are just getting by, not ahead. These villages, collectively known as Hoodland, are not the kinds of places one stops and spends much time. Instead most people traveling to the mountain from the Willamette Valley pass right through, stopping only if gas or caffeine are running low. A few miles past Alder Creek, the first of these hamlets, a sign welcomes travelers to the Mount Hood Recreation Area. Most drivers probably do not notice the sign; it is set back 50 feet or so from the road and, when the grass is high and leaves are on the trees, is partially obscured. To those who do notice it, though, the modest sign is perhaps the first evidence that they are not entering an elite destination area.

What is missing on this access road is a definite destination. Large, wood-androck, Cascadian-style signs on Highway 26 welcome travelers to Government Camp, but it is easy to speed right past and not even realize it is there. Or to think it is nothing more than a run-down rest area and a Department of Transportation facility. If the welcome signs do not alert drivers to the unincorporated village's presence, the Mount Hood Brewing Company and Mount Hood Inn are also visible from the highway, indicating that there might be something more to this place. 


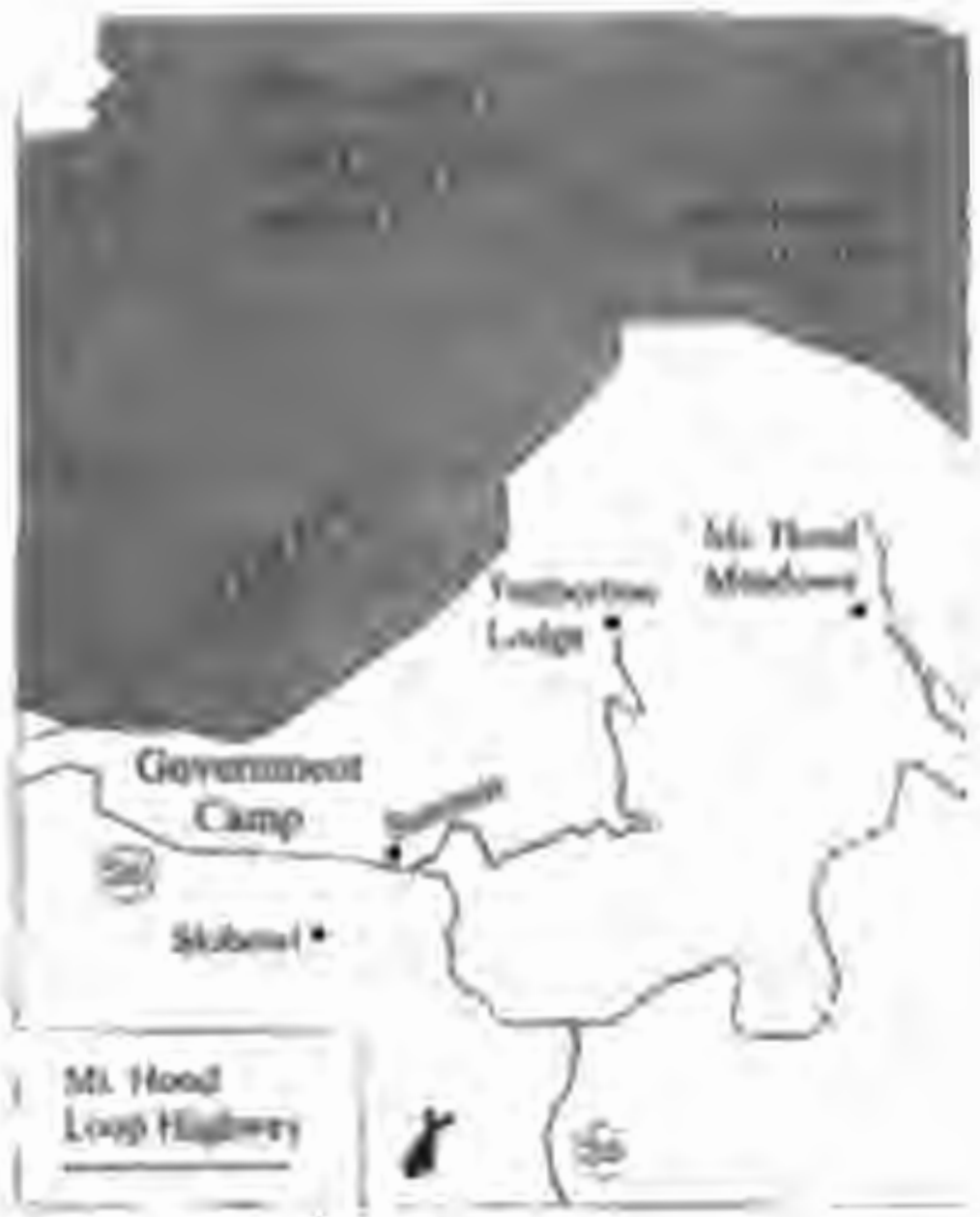

Figure 6. Sowth side of Wount Hoot

If the traveler docs make the rurnolf and finds the corc of Goverment Camp, it is unnoistakably a tourist spot. Contributing to this impression is its isolation. Surounded by national forest, there is nothing lor a number of miles to cater wo other Than toujism. Linlike Rarkdale, the types of busincsses make it clear that recreation and lourism is obviously the primary function herc.

Govemment Camp has a more complete suite of tourism establishnents than Parkdale. There are a scveral hotels and inns, a number of bars and layems, and a fory ski and snowbord shops, But the overall impression is not one of prospetity . Many 


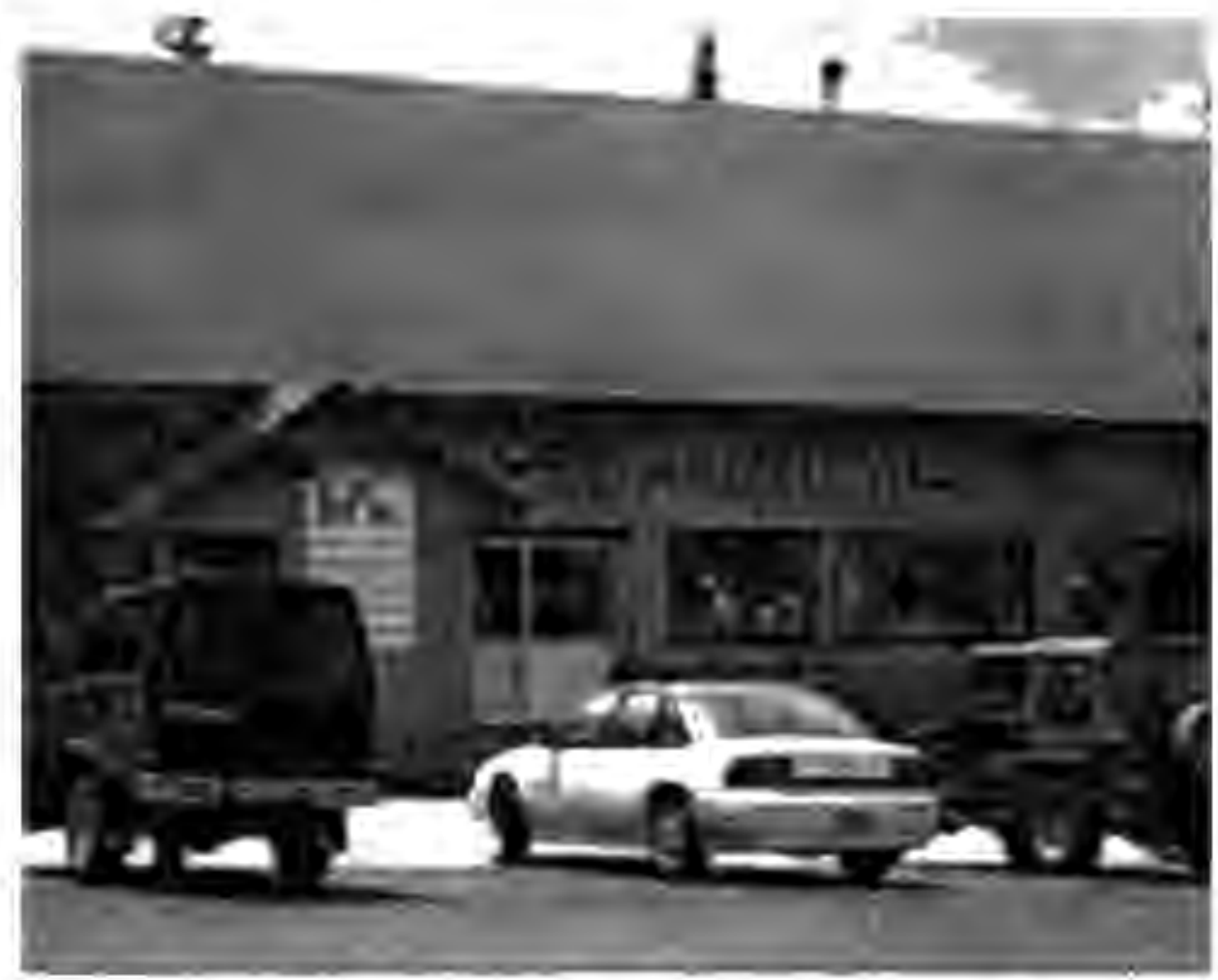

Figute 7. Chartic's Motunain View Restauran, Government Camp

butildings have a wort appearance that many gears of harsh winters without improvements will inevitably produce. The cozy coffee shops, upscale restaurants, and art gallenes that are tommon in large destination areas arc conspicuonsly absent here. One does not find many postcards witl photos of Government Camp.

There ate at suprising number of homes behind-just to the north of the central core of Government Camp. The residences run the gamut from shacks to upsealc homes with three-car garages. An exclusive suhdivision has posted signs warning trespassets that the area is for members only and violitors without parking permils will be Lowcd. Untij tecently most fesidential strets werc unpaved. 
Clackamas County is trying to reverse the village's plight with economic development efforts, and a hopeful feeling of change is tangible. Streets have been repaved, and new sidewalks and streetlights have been constructed. The Mount Hood Museum and Cultural Center has opened in an old bed and breakfast at the east end of the core area. The building has been renovated with Cascadian architecture in an effort to start to tie the village together with a consistent look. Excavation work for a new lodge has begun in the heart of the village core, and condominiums have been built in the nearby Collins Lake area between the main highway and the loop road. These improvements have caused the Oregonian to question if Government Camp is turning chic (11/14/2004). While they are tangible signs of change, they also stand in stark contrast with and highlight the rundown character of many of the buildings in the village core.

Two ski areas are within walking distance of the center of Government Camp. To the east of the village core, between the gas station and the rest area, sits the Summit Ski Area. This modest area was identified in a Forest Service winter sports planning document as an example of the importance of keeping small areas viable. "Summit Ski Area ... has been a main stay in the Portland, Oregon, area for giving young people an economical opportunity to develop skiing skills" (Wingle1994, 35). The area's lodge matches the decades-old motif of the village core. It also follows a curious trend, among rural tourism outposts with little else to offer, advertising espresso for sale. 


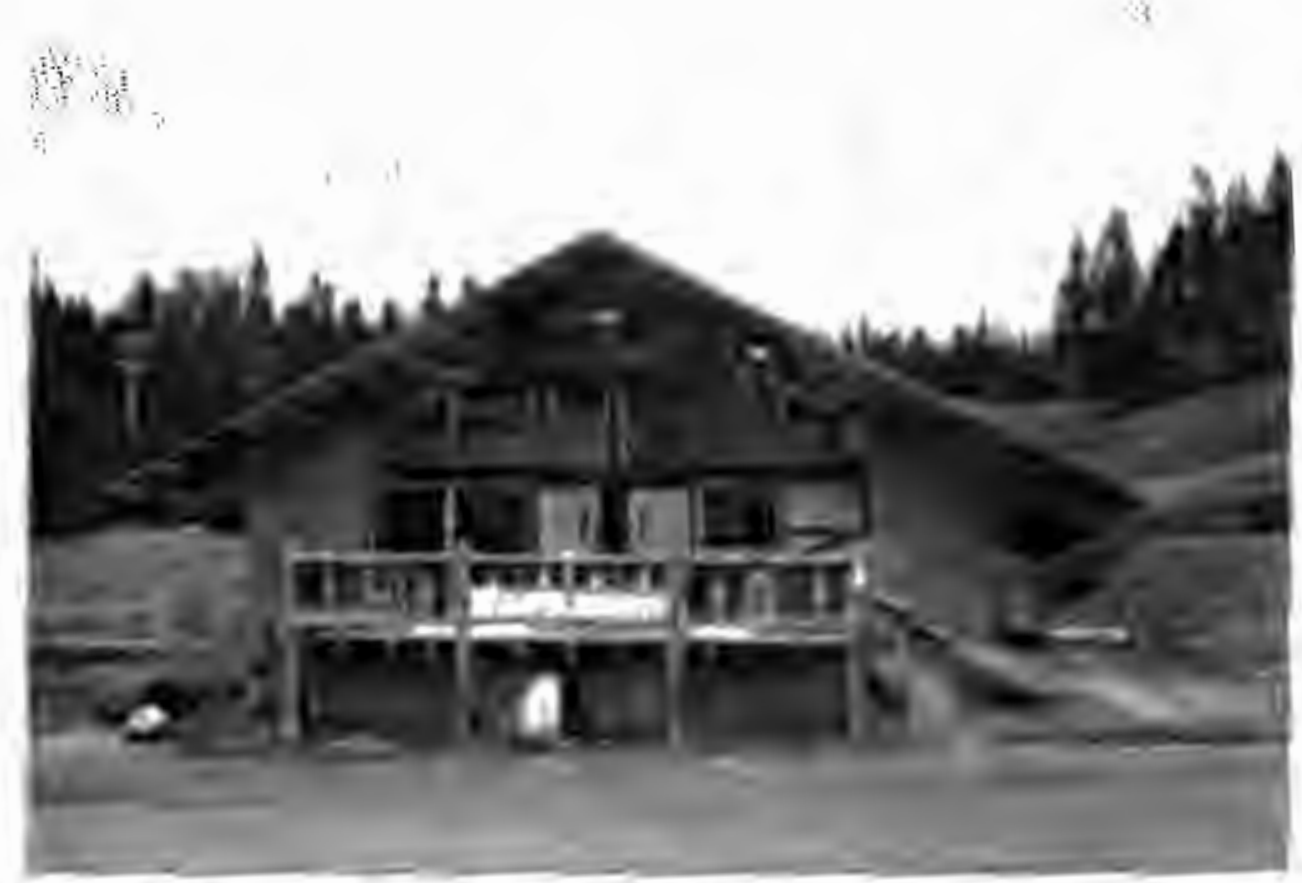

Regare of Surman shi Area, Goternment Camp

The Mount Hood Skibow area is south of Govemment Camp across Highway 26. It is within walking distance but requires either crossing four Janes of traffic that is rushing hadlong between the Willametle Vallcy and castcm Oregon, or using a nartow overpas from the center of the viliage. The ski area has inteconnected tertain and tils on Multorpor Mountain and Tom, Dick and Harry Mounlain. There is a smattering of day lodges and other structures at base atras at the botton of cither mountain, and t number of condominiums and homes near the base ont the Multorpor side. During the stmmer, the ski area is home to an alpine slide, motntain bike park, and action park with butgee jumprong, go-cats, and miniature golf, among other detivities. 
Five and a half miles and two thousand feet up a winding road from Government Camp, Timberline Lodge and ski area sit at the base of a broad, gently sloping apron that fans out on the south side of the mountain. The lodge itself is burly, rustic yet refined, seemingly a perfect match for the mountain. The relatively modern Wy'East Day Lodge stands in contrast to Timberline. Ski lifts and canyons frame the base area. From the Pucci Glade up to 8,000 feet on the Palmer snowfield, the lifts leave little doubt of recreation's role on the south side. White River Canyon to the east is a reminder of the mountain's wild heart.

While the landscapes of Government Camp leave little doubt that tourism is the lifeblood of the village, it has the look of a destination whose prime was several decades ago. The pervasive quiet found in the village on most days contributes to that feeling. The contrast of recent infrastructure improvements with the weathered buildings that house long-time businesses reflects a certain ambivalence toward change, progress, and tourism in general. 


\section{Early Recreation and Tourism:}

$1845-1940$

\section{"A sight so nobly grand"}

When Samuel K. Barlow first viewed Mount Hood from the Blue Mountains of eastern Oregon in October 1845, recreation or adventure for its own sake was likely the furthest thing from his mind. But he foreshadowed the mentality of twenty-firstcentury mountaineers when he proclaimed, "God never made a mountain without some place to go over it."

On the trail six months since leaving Illinois, his party was in a hurry to get across the Cascade crest before winter set in, and to claim a piece of the fertile Willamette valley upon which to build their new lives. When they reached The Dalles they found the cost of a bateaux to take them down the Columbia River's infamous rapids to be too great and the wait too long. Despite admonitions from locals, Barlow decided to set out and cut a road across the pass on the south side of the mountain that he had seen from the high perch of the Blue Mountains. Despite their urgency and the serious business of breaking a new road across rough and unknown terrain, they wondered at the mountain's beauty like so many of the explorers who would follow them. Joel Palmer, a member of Barlow's party who is considered to be the first white man to climb high on the mountain's flanks, began an otherwise unsentimental 
description of the mountain by saying "I have never before looked upon a sight so nobly grand" (Palmer 1994).

The highway that followed the general course of the Barlow Road would eventually carry climbers, skiers, and campers by the thousands from the Willamette Valley to Government Camp, but it would be several decades after Barlow first passed through before recreationists regularly traveled the road back to the mountain. "The route was one way-west-for its first fifteen years, until a road was blasted out around Laurel Hill" (Tompkins 2004). Even after Laurel Hill— which many travelers of the Oregon Trail claimed to be the single most difficult portion-was tamed, the journey to the south side of the mountain on the Barlow Road remained an arduous one, and travelers were subjected to as many as five tolls on the way. Most people who visited Government Camp at this time came from eastern Oregon (McNeil 1990).

A Portland party is generally given credit for being the first to the summit in 1857, and a handful of climbers followed in their footsteps in the years after. By the 1880s a few pioneers who settled in the meadows near present-day Government Camp were guiding a small number of adventurers who traveled the road back to the mountain.

It was during this period that Portlanders developed a curious fascination with illuminating the mountain with fire. For a short time, climbing to a point high on the mountain's west side and setting an enormous bonfire in hopes of being seen in Portland was a perfectly appropriate way to celebrate the Fourth of July. The stunt was first attempted in 1873, but it was not until 1887 that a party led by William Gladstone Steel first succeeded in igniting a conflagration visible from town. This example of 
American boosterism at the turn of the twentieth century provided a name for a prominent landmark on the mountain (Illumination Rock), but more importantly it is a symbol of the increasing orientation of activity on the mountain toward Portland.

\section{The first tourist resort}

With the completion of the railroad through the Columbia River Gorge in 1882, travel to Hood River from Portland became relatively easy. It did not take long for the idea of a tourist retreat on the north side to take hold. The following year four Hood River men scouted the timberline area for a good place to open such a resort. Their Mount Hood Trail and Wagon Road Company built the first road south of the crossing of the middle fork of the Hood River in 1884-85, and Mount Hood's first resort opened at nearly 5,900 feet. The tent camp run by Mrs. David Cooper, wife of the man for whom Cooper Spur is named, included a cook tent, a dining tent, and sleeping tents for guests. Despite its modest appointments, the camp was known for its hospitality and its proximity to the mountain's upper reaches. Mrs. Cooper cooked and tended camp, the Cooper children provided meals of trout and venison, and Mr. Cooper guided guests over the upper slopes of the mountain.

The Coopers operated the resort for only a few years before selling the company and road to William Ladd and C.E.S. Wood of Portland in the spring of 1889. As is often the case when tourist spots come under new ownership, change soon followed - the first being the name of the company to the Mount Hood Stage Company. Also a precedent for future trends in the tourism industry was the 
dependence on immigrant labor. Reconfiguration of the road, including the hand grading of "China Hill," a section of road just below resort site with a 22 percent grade, was done by Chinese immigrants newly arrived in the valley. Despite this steep section, the trip from Hood River was only a five- to six-hour trip, completed with three separate stages and teams of horses.

Cloud Cap Inn was built on a knoll on Cooper Spur just above the tent site in the summer of that year. The inn was designed in a rustic style that, starting with Depression-era public works projects, would become the norm for recreation sites built and managed by federal agencies. The style's underlying goal was nonintrusiveness that "achieved sympathy with natural surroundings and intimacy with the landscape" (Throop 1995: 10). Built from local Pacific Silver fir logs that were not "too unblemished in their appearance" and irregularly-shaped rocks from nearby cliffs, its roof would support heavy snow loads "without establishing too great a vertical emphasis that would dominate the scene" (Throop 1995:10).

The inn was completed in August and had six visitors before winter set in that year. Just 88 guests visited Cloud Cap in 1890. The Mount Hood Stage Company was operating in the red. At the end of the year they sold the transportation livestock and announced the inn was closed.

\section{A public lands base map}

When Cloud Cap Inn was built, the land on Mount Hood was still in the public domain, waiting to be claimed by enterprising citizens. No national forests or agencies 
to determine the propriety of such recreation developments existed. The federal government had enough difficulty in preventing land grabs that resulted from loopholes in the Donation Land Claim and Timber-Culture Acts. Concern with such abuses of public land disposition policy grew (Williams 1998).

Local and state recreation interests, led by William Gladstone Steel and John B. Waldo, worked for over a decade to create some form of forest reserve in Oregon. The establishment of a reserve in 1886 that would become Crater Lake National Park was the most prominent result of their work. In 1887 Steel helped to organize the Oregon Alpine Club with fellow climbing enthusiasts. "This club and its successor, the Mazamas, played much the same role in the forest conservation movement and park movement in Oregon that the Sierra Club did in California" (Rakestraw 1955:29).

In 1891, at the urging of the American Forestry Association, which included the current and former chiefs of the U.S. Department of Agriculture's Division of Forestry and the Interior Department's General Land Office (GLO), Congress included in a general land law reform bill a rider that became known as the Creative Act, or Forest Reserve Act. The legislation gave the President authority to "set apart and reserve, in any State or Territory having public land bearing forest, in any part of the public lands wholly or in part covered with timber or undergrowth, whether of commercial value or not, as public reservations ..." Any reserves set aside would be administered by the GLO (Loomis 1993; Steen 1976; Williams 1998).

The city of Portland successfully lobbied the Department of Interior to create the first forest reserve in the Northwest in 1892. The 142,000-acre Bull Run 
Timberland Reserve was established to protect the rapidly growing city's water supply. But Steel and members of the Oregon Alpine Club set their sights on a far bigger prize. An ambitious petition drive by OAC members, the Chamber of Commerce, and Hood River interests along with a personal lobbying effort by Steel in Washington, DC, helped to win the designation of the Cascade Range Forest Reserve in 1893. The largest reserve in the nation at almost 4.5 million acres, it stretched 235 miles from Mount Hood to Crater Lake. The reserve faced fierce opposition, particularly from local stockmen who wanted it drastically reduced in size or eliminated altogether. ${ }^{3}$ But continued efforts by the Mazamas, the newly formed successor to the Oregon Alpine Club, and another exhausting and expensive lobbying effort by Steel in DC helped preserve the reserve (Rakestraw 1955; Williams 1998).

The Organic Act of 1897 established timber production and water supply protection as the official purposes of the forest reserves, and proponents of the Cascade reserve used largely utilitarian arguments to win its designation. They eventually accepted grazing on the reserve in order to ensure its continued existence (Rakestraw 1955). The transfer of the administration of the forest reserves from the Department of Interior to the Department of Agriculture in 1905 emphasized the commodity value of forests at the time. Furthermore, the 1907 Fulton amendment,

\footnotetext{
${ }^{3}$ The Forest Reserve Act did not provide specific guidelines for administration of the reserves, so the Secretary of Interior initially "construed reservation as withdrawal not only from sale and entry but from any use whatsoever" (Rakestraw 1955:53). Grazing on forest reserves was thus prohibited along with most other uses. After the Organic Act was passed, the General Land Office issued regulations making reserves in Washington and Oregon the first to allow grazing in 1898. Foresters believed that the Northwest's ample rainfall "supported vegetation of sufficient quantity to withstand grazing pressures" (Steen 1976: 65).
} 
which repealed the President's right to establish reserves under the Forest Reserve Act (after Oregon's own Senator Charles W. Fulton) of 1891, included a change in name of the forest reserves to national forests. The change, urged by Forest Service chief Gifford Pinchot, further clarified that the forests were not to be preserved, but rather used for society's benefit (Loomis 1993).

It would be a number of years before recreation was broadly considered a legitimate use of the forest reserves. But with the establishment of the Cascade Range Forest Reserve, Portland recreationists helped to establish a base map that would guide future administration and management of forests on Mount Hood. This invisible layer of federal land ownership would affect the future spatial organization, identities, and cultural landscapes of Mount Hood. Portlanders helped to ensure the philosophical and geographic foundation for future recreation efforts on what would become the Mount Hood National Forest.

\section{National park proposals}

It was not long before Portlanders advocated greater protection of Mount Hood in the form of a national park. A nationwide movement for greater protection of natural, scenic, and recreational values of forestland had gained momentum. Transcendental philosophy of Emerson and Thoreau that recognized a spiritual value of nature combined with the Turnerian-like association of wilderness with America's pioneer past drove an increasingly urban society to place greater value on wild country. The Organic Act clarified the role of the forest reserves, and the feeling that the reserves 
would not adequately protect non-utilitarian values of the forests grew stronger (Nash 1982).

Despite skepticism about the forest reserves, the alternative was not particularly clear. The national park idea was still in its formative stages at the turn of the century. Protection of the environment was not the primary role of early national parks. Instead they were created to protect outstanding scenery, monumental landforms, and unique natural wonders. At the time of its creation in 1864, Yosemite included only the immediate area around Yosemite Valley and the Mariposa Groves of Sierra redwoods. Yellowstone Park was much more encompassing at 3,300 square miles, but its size was intended only to protect any natural wonders that had not yet been discovered. Some early parks advocates, including John Muir and Frederick Law Olmsted, advocated an appreciation of the parks that went beyond the most spectacular scenery. "Tourists make their way through the foot-hill landscapes as if blind to all their best beauty, and like children seek the emphasized mountains-the big alpine capitals whitened with glaciers and adomed with conspicuous spires," Muir lamented before predicting that eventually "lowlands will be loved more than alps, and lakes and level rivers more than water-falls" (Muir 1875 in Runte 1977).

Adding to the uncertainty of the park ideas was the fact that no central bureau for managing national parks existed. While Yosemite was managed by California, the U.S. Army administered Yellowstone. National monuments created under the 1906 Antiquities Act, many of which were the predecessors of future parks, were nearly 
equally divided between the Forest Service and the Department of Interior in 1911 (Runte 1977).

If the specific purpose and oversight of the parks were unresolved, their permanent inviolability was made a priority early on. The legislation that created Yosemite declared that it was to be held "inalienable for all time." This concept of permanent protection made Yosemite the first of its kind, but because its administration was immediately turned over to the state of California and it was not called a national park at the time, the distinction of being America's (and the world's) first national park-and the model for future parks around the world—went to Yellowstone, created by Congress in 1872 (Runte 1977).

Early park advocates also wanted to limit the imprint of human development in parks. Insecurity over the lack of cultural heritage was a motivating factor in the development of the national park idea, and tacky commercial development like that at Niagara Falls, the country's most significant scenic attraction in the first half of the nineteenth century, did nothing to help the image of an unsophisticated American society. If Olmsted and others wanted to prevent an amusement park atmosphere in the parks, they certainly wanted to prevent extractive industries and other intrusions such as dams. The fact that early parks were established primarily in areas considered to be otherwise worthless helped to reduce the likelihood of these kinds of activities, but a conflict over just such a development was on the horizon.

Much of the uncertainty and ambiguity of the national park idea came to a head with the controversy over damming Hetch Hetchy Valley in Yosemite National 
Park. The issue drew clear lines between Pinchot's progressive conservationists who espoused the most efficient use of forest products for the material advancement of society and John Muir's "preservationists" who valued nature for its intrinsic value and for the spiritual renewal it provided. Muir and the preservationists ultimately lost Hetch Hetchy to a reservoir, but the mere fact that the controversy raged for five years was testimony to the power of preservationist sentiment and was a catalyst for the creation of agency to protect and manage national parks (Nash 1982; Runte 1997).

Thus at the beginning of the 1910s there was significant ambiguity regarding the purpose and administration of national parks as well as the process for establishing them. These ambiguities are reflected in a hodge-podge of park proposals for Mount Hood in the several decades that followed. The earliest proposal for Mount Hood was advanced in 1911 when the superintendent of Portland Parks wrote to the Secretary of Agriculture to request that the mountain be withdrawn from what had become the Oregon National Forest in 1908 and elevated to park status. It is not clear what became of this request, but little more was said of the issue until 1915. Chief Forester Henry Graves wrote to Oregon representative N.J. Sinnott to express his support for a highway encircling Mount Hood. Perhaps to quell any lingering park sentiment in Oregon, Graves, who was adamantly opposed to a separate parks bureau, also outlined his objections to such a plan. If it remained in the National Forest, Graves argued, "the timber, range, mineral, and other resources could be developed collaterally with the scenic features" (Oregonian 6/30/15). 
The furthest any park proposal would advance was a bill introduced by Oregon Senator George Chamberlain in January 1916 and endorsed by Secretary of the Interior Franklin K. Lane that included Mount Hood in a large 688-square-mile park. The park was to be administered by the Forest Service to ensure the continued construction of roads and other developments. Officials in Portland, concerned with the city's water supply from the Bull Run reserve, immediately balked, but Chamberlain allayed their fears by announcing that the park would not include the reserve. Protests by stockmen were not put off quite as easily. In summer of that year an alternative for a chain of eight smaller parks was proposed, and in fall Chamberlain agreed to try to prevent the plan for one big park from going through. The bill died in committee not long after legislation creating the National Park Service was passed in August 1916.

A number of other proposals for a national park on Mount Hood surfaced over the next two decades. Expectedly, opposition came from timber and grazing interests, but the National Park Service itself was cool to the idea. In 1925 Director Stephen Mather declared that the mountain would never become part of the National Park system, alluding to the concern with weakening national park standards by admitting areas that bore too great a human imprint. "There are too many limitations involved. Within the area which would have to be included in a national park are vast private timber holdings, some of which are being logged. The Bull Run forest reserve, from which Portland gets its water supply, is also within the area" (Portland Telegram 7/9/25). Instead he suggested the City of Portland or Multnomah County acquire it, 
pointing to successful efforts by Los Angeles and Denver to create parks in nearby forests.

A.E. Demaray, acting director in Mather's absence, again raised the issue of standards after a proposal by a committee of the Multnomah Anglers and Hunters' Club in 1928. The 1916 bill "recognized the futility of creating a park here on the same basis as other national parks" by proposing that the new park be administered by the Department of Agriculture. Park status was even more objectionable given new development on the mountain since Chamberlain's proposal. "Extensive private holdings, water supply projects, power site withdrawals and extensive grazing problems" were the most significant developments that "would have resulted only in the breaking down of standards set up for the national parks." Furthermore, Demaray suggested that, intensive development aside, Mount Hood simply might not be national park caliber. "[I]t has become an established policy of this service to uphold the highest standard of national park development to limit as far as possible admission to the national park system of only one example of a particular type" and Mount Hood would have been a "duplication of a type already well exemplified in Mount Rainier National Park" (Oregon Journal 11/14/28).

The final attempt (until the most recent in 2004) came in 1939 when Interior Secretary Harold Ickes proposed a number of national parks, including one encompassing Hood and Timberline Lodge. But this was no more successful than his attempt to transfer the Forest Service to the Interior Department. Significantly, the Oregon Winter Sports Association and other advocates of more developed forms of 
recreation were among the most vocal opponents of Ickes' plan. "Residents of the region [believe] the present [Forest Service] supervision is in all respects convenient and admirable.... "National Park Service [administration] would be arbitrary and restrictive... The selfsame elements of probable regimentation and departmental red tape would tend to jeopardize the fullest popular enjoyment of the Mount Hood recreational area" (Oregonian 5/25/39).

\section{Recreation grows}

In the years after the designation of the Cascade Range Forest Reserve, recreation and tourism began to grow on Mount Hood. Government Camp became more than a collection of homesteaders' cabins in the 1890s. Oliver C. Yocum, a guide on Mount Hood since 1883 , had filed a homestead claim in 1892 , shortly before the creation of the reserve would prevent such a claim. His claim adjoined that of his close friend, Will Steel, and the two built a cabin that straddled their two claims, fulfilling the government requirement to build a residence. Their homestead was the main staging area for the large climb during which the Mazamas was founded in 1894. In 1899 Yocum built the village's first hotel with 16 rooms. He platted the village in 1900 and applied for a post office, officially putting Government Camp on the map.

Recreation and tourism continued to grow on the north side of the mountain as well. Cloud Cap Inn re-opened in 1891 with less extravagant service. The resort's guides pioneered new summit routes on Cooper Spur and Cathedral Ridge, and led guests on excursions all over the mountain. Members of such prominent Portland 
families as the Ladds, Glisans, and Corbetts organized the Snowshoe Club in 1904. The club made annual winter outings to Cloud Cap Inn until 1910 when it built its own cabin just north of the inn. Another hotel soon opened on the north side. Homer Rogers, a Yale educated New Yorker, came to the Hood River Valley in 1909 to try his hand at orcharding. Rogers had done some climbing in the Alps and his attention soon turned to the mountain in his backyard. In 1913 he converted the home he built on the Cloud Cap Road into the Mount Hood Lodge, and offered guiding service on the mountain, horseback riding, and skiing instruction. He was well connected with Portland's social elite, and his inn combined rustic charm with high society sophistication.

David Eccles' Oregon Lumber Company built the Mount Hood Railroad to its mill in Dee in 1906. In 1910, the railroad was extended to Parkdale to carry timber and fruit from the upper valley, and the railroad's vice president immediately started excursion trains to promote the line with various business interests. The Parkdale Hotel opened in 1912, and in 1915 the railroad ventured into the tourism business, offering a package trip that included rail travel to Parkdale, wagon transportation to the forest boundary, guide service up Mount Hood, and dining and bedding at Cloud Cap for $\$ 5.50$ per person. The following year regular passenger service between Hood River and Parkdale started.

Upper valley residents exhibited what was perhaps their earliest resistance to tourism during this period when they formed the Upper Hood River Valley Progressive association to file a complaint about the line's operations with the state 
railroad commission. Regular service to Hood River took over three hours while excursion trains made the trip in just over an hour, they complained. The commission took no formal action but strongly suggested that the operators adjust the schedule to provide better service to businesses in the upper valley. The railroad was able to shorten the trip by approximately an hour.

The valley's pastoral landscapes had appealed to the earliest tourists in the valley. One visitor to Cloud Cap Inn in 1893 remarked that on her retum trip to Hood River, "One of the most beautiful views we got ... was a grand pine filled canyon on the slopes of which every now and then would peep out prosperous little farms with its fields of cut hay and swaying grain shading off from brilliant green to gold" (Russell 1978:210). By the early twentieth century, orcharding had become well established in the valley, and in mid-April blossoming fruit trees carpeted the valley floor. The fragrant blooms attracted visitors from Portland and other smaller cities in the region as early as the 1910 s.

Despite their differences, orchardists and the railroad both worked to promote the valley among residents of the region. In spring 1912 the city of Hood River organized a weekend-long celebration of the orchard blossoms, during which they hosted the Portland Commercial Club and the Portland Press Club. The visitors were lavished with banquets and tours of the valley. In a gesture that was symbolic of the early intersection of agriculture, timber, and tourism, the railroad, its engine decorated with pine boughs and blossoms, carried the guests to Parkdale, where the town's women served them lunch (Oregonian 5/5/12). 
The increasing availability of the automobile helped advance tourism on the north side for a short period. The first car arrived at Cloud Cap in 1907. Soon after an auto stage cut the trip from Hood River by over half and brought a period of prosperity at the inn. But the ease and convenience of auto travel would eventually mean the demise of the retreat. "Automobiles were somewhat later in coming to the south side. . .. But they came, and served eventually to outdo development of resorts on the north slopes" (McNeil 1990:57).

\section{The transportation network}

After the creation of the National Park Service in 1916, the animosity between the utilitarian conservationists and the preservationists was reflected in the great rivalry between the Forest Service and the Park Service. Most new national parks were created from national forests, and largely in order to stymie this trend, the Forest Service eventually accepted the role of recreation on national forests (Steen 1976). It was in their interest to promote recreation development on Mount Hood and the agency's management focus on the mountain during these years shifted decidedly in that direction.

Appreciation of the mountain's natural amenities was beginning to spread beyond that of the Mazamas and the other members of the elite climbing community who fought for the establishment of the Cascade Range Forest Reserve. With the advent of automobile travel, tourism and recreation was democratized, and many of the people who were drawn to the mountain were not interested in roughing it quite as 
much. In addition, some Portlanders realized there was money to be made from tourism and recreation.

The "See America First" campaign of the early 1910s attempted to persuade American tourists to visit their own country's scenic wonders rather than travel to, and spend their money in, Europe. National parks advocates used this form of cultural nationalism-touting the superiority of American scenery and the economic benefit it provided through tourism - to strengthen their cause (Runte 1997). By the time conflict in Europe had disrupted international travel, communities all over the country embraced the idea. Portlanders were only following the national trend when they looked to its hinterlands to earn the tourist dollar (Oregon Journal 10/5/14). The campaign was renewed with vigor after the war, and a group of Portland businessmen formed the Mount Hood Development Committee "whose prime object should be the intensive development of Mount Hood as a tourist destination" (Portland Telegram $8 / 11 / 21)$.

The Mount Hood Loop Highway

The first order of business in developing Mount Hood's tourism potential was the issue of access. The first automobile to be used in the stage service to Cloud Cap Inn in 1907 reduced the travel time from Hood River from eight hours to three, but the most direct access to the mountain was on the south side. Sam Barlow's toll road to Government Camp had changed hands several times since he opened it in the summer of 1846. Various operators of the road had laid corduroy and planks in the particularly 
wet areas, and the first automobile made it to Government Camp in 1903, but the track was deeply rutted, and chains were often required on all four wheels to make the arduous journey. One prominent Portland businessman described the problem succinctly:

We've been kept out of millions of dollars of tourist money through the lack of [a good road]. We've not been able to prevent visitors from doubting that we have such a scenic asset because they have not been able to reach it. Tourists of the class that spend $\$ 100$ a day have passed through Portland and passed us by, going to places with scenery less beautiful but more accessible (Oregon Journal 8/15/14).

He suggested that a Mount Hood road committee be formed and offered to match any funds pledged by members for improvement of the road and the survey of a route that would completely encircle the mountain, connecting with the soon-to-be-completed Columbia River Highway. The following week the Oregon Journal pledged $\$ 100$ toward the effort.

Supporters believed that only 23 miles of new road were needed to connect Government Camp with the Upper Hood River Valley. Chief Forester Henry Graves and T.S. Schuyler, head of the federal highway department, both endorsed the idea. In the summer of 1915 Multnomah County Commissioner Rufus Holman organized two parties to scout the route, and shortly after, Schuyler surveyed the road, determining that it would be 37 miles. By the end of the year Oregon congressman C.N. McArthur drafted a bill to finance the road with advances on timber receipts paid to the Oregon Schools fund. But shortly after Senator Chamberlain's proposal for a national park in 
January 1916, the Forest Service's support for the plan understandably waned. Any further progress on the plan was delayed by the United States' entry into World War I.

The idea was revived again in early 1919 . The state highway commission accepted the old Barlow road from the estate of Portland businessman E. Henry Wemme (who removed the toll in 1915) and the Mount Hood Loop Road Association was formed. The Forest Service must have felt confident at this point that national park status was not likely to be conferred to Mount Hood; in March the agency agreed to share with the state the cost of improving the portion of the road on the national forest. Despite cost overruns, the first leg of the loop from Zig Zag to two miles past Government Camp was completed by the next year.

The portion of the road outside of the forest boundaries, however, was to be financed by the counties. Clackamas County did not have the funds to improve the road, so Multnomah County initially agreed to finance the portion between Sandy and the forest boundary at Zig Zag. Portlanders justified the expense on the grounds that it was in the county's best interest in the long run to make the mountain available to tourists. In the previous year private property owners had spent $\$ 2,200$ to make the road passable with planking. But Multnomah County became hesitant to pay for road improvements in another county and balked. The state highway commission had already paid for grading the road and construction of bridges, and refused to pay for the surfacing until Multnomah County upheld its commitment. In a public meeting the citizens of Portland urged the county commissioners to fund the project. It took three years of prodding before the county would commit funds. 
On the north side, Hood River County passed a bond measure in June 1921 despite objections by valley farmers that the road would not pass through the main shipping points of Parkdale, Odell, and Van Horn. The people of Parkdale had a change of heart by time the road was ready to be officially open in the summer of 1925. In mid-June the town offered to clear the route of remaining winter snow so that tourists could make it to the annual strawberry festival the following week.

An estimated 15,000 people made the trip when the loop road opened for its first year on June 21, 1925. A number of changes to the route would be made over the years, but the basic structure of the major transportation network around the mountain had been established. The loop road was touted by many tourism boosters but had the ironic affect of putting some establishments out of business. "The summer hotels [in the Cascads] flourished until the late 20 's, but then most became the victim of the transportation revolution. Most are now abandoned, their purpose outlived; the former two-day trip to Portland is now but an hour's drive" (Rakestraw 1955: 29). Homer Rogers Mount Hood Lodge was one such casualty on Mount Hood (Grauer 1975).

\section{Lolo Pass Road}

Although timber and agriculture had become the primary industries in the Hood River Valley, tourism here still rivaled that of the south side. As the movement to improve the road from Portland to Government Camp gained traction, Hood River Valley interests began advocating a road over Lolo Pass on the mountain's northwest flank. From the earliest days of the Oregon Trail, immigrants drove their cattle along the old 
Indian trail while their families and belongings went down the Columbia on a raft or bateaux. The route followed the West Branch of the Hood River, over the pass, and down the Sandy River basin to the Willamette Valley. It was not an easy route--part of the reason for Barlow's decision to go around the south side. In 1859 Captain A. Walker attempted to build the road in an effort to win over some of the Barlow Road traffic, but fires in the surrounding forest cut short his efforts that year, and he never completed the road.

Hood River and Portland interests pushed again for the completion of the route in 1910. In 1914 a Hood River resident circulated a petition in Hood River, Portland, and Salem, requesting Chief Forester Graves to build the road. The Forest Service supported the proposal, citing the benefit the road would provide in fire protection, and by 1915 had built the first $3 \frac{1}{2}$ miles. The road met stiff resistance from the Portland water bureau, which was concerned with the affect on the city's water supply in the Bull Run Reserve. Inaccurate maps of the era placed Bull Run Lake farther to the southeast than it actually was, and the reserve boundary included an entire township that was not in the watershed. The new road would pass directly through this parcel. The project was again abandoned, but not without ongoing controversy. The error was recognized by the early 1920 s but was not corrected.

Proponents of the road lamented the lost recreation opportunities on the west side of the mountain and the unrealized tourism business in the Hood River Valley. Keeping the road closed would, of course, be in the best interest of Portlanders who favored recreation development on the south side of the mountain. At least one 
researcher has suggested that a deal was struck in which the Forest Service agreed to promote the Barlow Road route and recreation development on the south side of the mountain if national park advocates in Portland backed off their proposal (Burtchard and Keeler 1991). The 1926 designation of the 83,000-acre Mount Hood Recreation Area "for the use and enjoyment of the general public for recreation purposes" on the south side by the Secretary of Agriculture would seem to support this theory. Whatever the case, resolution of the Lolo Pass controversy would be several more decades in coming.

\section{Mount Hood gains new fame}

As touted, the opening of the loop road brought a surge of new tourism interest and development. Anticipating the road's completion and Mount Hood's growing status as an icon, the Forest Service renamed the Oregon National Forest in 1924. Mount Hood National Forest "has long been a playground for Portland people and is destined to become the pleasure ground for thousands of people, not only from the entire Northwest but all over the United States" (Forest Service 1924). This change was concomitant with a series of development proposals and policy initiatives that would shape Mount Hood's landscapes and identities for generations.

\section{The Cableway Controversy}

Not long after the loop road opened, a Portland company proposed a project that would test the degree to which recreation development would be accepted on Mount 
Hood. In fall of 1926, the Cascade Development Corporation applied for a permit from the Forest Service to construct a cable railway from Cloud Cap Inn to the top of Cooper spur and a suspended cableway from there to the summit. The plan included a much larger hotel to replace Cloud Cap Inn at the end of the newly re-configured and surfaced Cloud Cap road, and a new observation station would replace the fire lookout cabin built in 1915 on the summit. The cableway was the first development project to stir a controversy of this magnitude on Mount Hood. Proponents of the plan anticipated the increased business it would bring to Portland, but it was also a matter of civic pride. Portland was still largely a remote, regional city. The "development of a tourist facility ... [was] essential if Portland was to be delivered from regional obscurity" (Rose 1986). Central to the debate were age-old themes and contradictions, and some just taking shape in this period, that would characterize similar conflicts in the future: Eastern hegemony versus local control, wilderness versus development, accessibility of natural wonders to the larger population versus elitist locking up of the land.

Forest Service chief William B. Greeley denied the initial application in April 1927. The Cascade Development Corporation appealed the decision, and proponents organized an ambitious letter-writing campaign to sway Greeley's opinion. They based their appeal not on the potential boon to business but on the access the cableway would provide to a broader range of people who might not have the ability or inclination otherwise to reach the summit but who deserved the opportunity nonetheless. On April 15 Greeley held a public meeting in Portland to hear public 
sentiment on the issue. In his address to the gathering, Greeley let it be known that, although he came with an open mind, he was also of the opinion that too much of the continent's wild land had been lost. Over a dozen business and civic groups came out in favor of the plan. Only the Mazamas, the Oregon Trails Club, and the Oregon Technical Council opposed the project. Greeley again denied the permit by the end of the month.

Proponents of the plan went over Greeley's head, appealing to Secretary of Agriculture William Jardine. In February 1928 Jardine requested a comprehensive evaluation of the matter by a committee of local interests. Not surprisingly the committee's four-page report heavily favored the project. Jardine saw through their bias and delayed his decision. He requested another evaluation of the situation by a team of objective experts in the field of parks, recreation, and landscape architecture. The new committee consisted of renowned landscape architect Frederick Law Olmsted, Jr., Dr. Frank A. Waugh, professor of landscape engineering at Amherst College, and Dr. John C. Merriam, president of the Carnegie Institute-all Easterners. Cableway advocates were incensed. They considered it a classic case of federal bureaucrats intervening in a local issue. Clearly, people who knew the area and were familiar with the issues were more qualified to evaluate the project than three "abstract theorists" from 3,000 miles away. Private interests were not the only ones to object. Oregon's political machine also mobilized. The Oregon legislature passed a resolution urging Jardine to rule favorably: The federal government should "pursue a policy of giving the local states ... opportunity for development, where not inconsistent with 
the basic reasons for creating such reserves" (Oregon House of Representative 2/22/29 in Beck 1986). In addition Oregon Senator Charles McNary, as chair of the Senate Agriculture Committee, likely exerted some influence on Jardine. But Jardine would not acquiesce, and the committee spent two weeks in the summer of 1929 evaluating the cableway project and the general recreation situation on Mount Hood.

In their report, the committee dismissed the "sentimental objections" of climbers who feel that rewards like those to be had on the summit of Mount Hood should be reserved for people who were willing to get there under their own power and who value the solitude such physical exertion afforded. "It is only people of weak or undisciplined imagination for whom such ideas [of large numbers of people reaching the summit by mechanical means] would be a permanent hindrance to appreciation of the mountain's finer qualities." But they did affirm the value of the wilderness character of such places. Developments like the cableway would be "insistent visible reminders that in reaching the vicinity of timber line one had not escaped for a time beyond the sophisticated and man-dominated region of everyday life into the borders of an ultimate and essentially untamed alpine wilderness" (Olmsted 1930: 27-28). The committee ultimately voted two-to-one to deny the permit for the cableway. The three agreed that in the long run the mountain would be of greater value and achieve greater fame without it. They believed the view of the summit from the "timberline region" was more valuable to more people than the panoramic view from the summit would be. Sacrificing the best values of the area as a whole for an "immediate popular detail" will set a precedent for the "gradual frittering 
away of the extraordinary potential of the area" (Olmsted 1930:33). Waugh voted in favor of the project on the logic that there was great demand for such a tramway somewhere on one of the Cascade summits, so it might as well be Hood. He also felt that denying the application would create animosity toward the Forest Service that would eventually threaten the same values that were threatened by the cableway.

The committee forwarded their report to the new Secretary of Agriculture, Arthur M. Hyde, in 1930. Hyde, who was more sympathetic of local concerns than Jardine, disregarded the committee's recommendation and issued the permit anyway. The project never proceeded. Cascade Development Corporation was not able to resolve financial difficulties before the Depression ended all possibilities of the plan.

The committee's report was as notable for its observations and recommendations on recreation in general on Mount Hood as it was for its decision on the cableway issue. The committee advised against private summer homes around Lost Lake (cottage sites had been available for lease from the Forest Service for ten years), recommending camp houses that were available to the general public instead. They also favored the primitive area that had been recently proposed. They supported the Lolo Pass road, but recommended not building roads into areas on the north and west sides such as Paradise and Eden Parks for fear of destroying the sensitive areas. They also advised against building the proposed road from Government Camp to timberline for fear of "convert[ing] all the vicinity of that place literally into a bare, dusty ash dump" (Olmsted 1930: 23). 
Also noteworthy in the committee's report is the characterization of what was becoming the recreation center of Mount Hood, Government Camp. They affirmed the reasons for the village's appropriateness as such a center. It had the greatest amount of private land within the national forest. It was closest to Portland and a road from the south. In contrast to the mountain's rugged north side, it had "considerable area of land topographically well adapted" to such a use at as high an elevation. The "general slope of the land rising up toward Mount Hood" was gentle enough to be inviting and allowed good views of the summit (Olmsted 1930: 33).

At the same time, however, they acknowledged the limits of Mount Hood's tourism potential and the less-than-appealing character of Government Camp at the time.

Opportunities such as occur in the Mount Hood area for winter sports ... although not notable in comparison with those commonly found in some other parts of the country, are so exceptional in the Pacific States as to give them considerable local and regional importance.... Government Camp village as it now stands, taken as a whole, is neither better nor worse than thousands of other popular resorts, more or less shabby, tawdry, crude, and unsatisfactory ... There is no inherent reason ... why there should not be gradually developed ... a really worth-while center of resort so attractive, so satisfactory, and so distinguished that it would rank in quality among similar resorts in America ... That is a high aim. Not the remotest symptoms of an intelligent effort to pursue such an aim are yet evident" (Olmsted 1930: 12, 33-34).

The committee attributed the village's unsatisfactory character to the lack of an organized planning effort and the focus of individual businesses on maximizing profit without regard to the improvement of the village as a whole. 
They made several specific recommendations for Government Camp, at least two of which would eventually be heeded: the creation of a lake and the bypassing of the main road around the village core. Some of their advice likely justified locals' outrage at the Easterners' intervention. They characterized the independent businessmen as "having much more of enterprise and self-confidence than they have of taste, skill, and knowledge of specialized technique for getting a high quality of results." When property owners "will not cooperate [with a planning effort], agencies of the State can acquire land or easements under power of eminent domain" (Olmsted 1930: 34-35). While sometimes naïve and condescending, this analysis by three highly respected experts in recreation and park development did portend the nature of future challenges and limits of recreation and tourism development on Mount Hood.

\section{Winter Sports}

In late 1926 the Advertising Club of Portland designated itself as the lead in the effort to develop winter sports on the mountain. "Mount Hood, in my opinion, is one of Portland's greatest civic assets. There is a chance on the south side of the mountain to build up a nationally famous winter playground. ... [Its] presence within two hours of Broadway and Washington streets would mean thousands of dollars in advertising for the city," claimed the club's president (Oregonian 11/24/26).

The state first kept the road to Government Camp open in the winter in 192627, and in December 1927 the Ad Club, with a $\$ 5,000$ investment, opened what would become Summit Ski area with a ski slope and a toboggan run. The area was popular 
immediately; the day after Christmas found 800 cars in Government Camp (Grauer 1975). Another area with a ski jump and toboggan and bobsled run opened a mile east of Government Camp, at Swim on the east end of Multorpor Mountain, that winter. The next winter the Cascade Ski Club opened a ski jump on the northwest end of Multorpor Mountain. These small areas became the sites of popular ski jumping contests featuring a field of mostly Norwegian competitors who worked in timber, agriculture, and other extractive industries. A February 1929 competition at Multorpor that drew some of the West's best jumpers was an officially sanctioned National Ski Association event, an indication of Mount Hood's entry into national winter sports scene (Grauer 1975).

The north side was also home to a budding interest in winter sports. The Hood River Ski Club hosted the first winter carnival in the Hood River Valley in 1926, with a race from Cloud Cap to the Homestead Inn near the present Cooper Spur Ski Area. They cut a jump hill near the inn in fall 1927, and the carnival that year included a jumping competition and a three-mile cross-country race. In 1938 residents of the Upper Hood River Valley formed a ski club of their own called the North Slope Ski Club. Clubs on either side of the mountain participated in each other's events (Grauer 1975).

In the early years of skiing, jumping was the primary form of the sport. But participation in this difficult and dangerous form of skiing was limited to a daring few. "The ski jụmpers were mostly Norwegians and often of the hard-drinking crowd. They were often rowdy and behaved like a bunch of ruffians," observed one jumper (in 
Arthur 1998). Some skiers were willing to hike up the slopes they wanted to ski, and then ski down at breakneck speeds with little turning control. Most of the people who were being drawn to the sport, however, were not interested in that level of rịk or in exerting quite that much effort. The more civilized social elite who came from Portland to the mountain were primarily spectators.

Two developments in the sport precipitated a change in the skiing demographic in the mid-1930s. The Alpine ski style eclipsed the Nordic style. The stem christie, introduced to Mount Hood by Swiss skier Fritz Bierly in 1931, allowed skiers to change direction with some manner of control (Grauer 1975). Otto Lang and other Austrians brought the snowplow-based Arlberg technique to the U.S. from Hannes Schneider's famous St. Anton ski school. Lang opened a Hannes Schneider ski school at Timberline in 1938. It was not long before rope tows were introduced to eliminate much of the work. That they allowed multiple runs in one day was an added benefit. The first tow was installed at Ski Bowl on Tom, Dick, and Harry Mountain in 1937, and others followed shortly after at Summit and the Mazamas' ski hill in Government Camp. On the north side, the North Slope Ski Club put in a tow near the Cooper Spur junction on the loop road in 1938, and the Hood River Ski Club built a tow on their jump hill near the Homestead Inn in 1940.

With the introduction of a safer, more controlled technique and quick transport up the hill, the sport became more accessible to a greater number of people, and for a period Mount Hood was an epicenter of winter sports in North America. Mount Hood was the most used ski area in the nation in the winter of 1937-38, with 115,000 skiers 
(Oregonian 2/22/39). Otto Lang's presence at Mount Hood was an indication of the cachet the area held at the time. Significantly, his departure the next year for Sun Valley, Idaho, foretold the industry's future migration to whiter pastures. One of the most prestigious races held on Mount Hood was also one of its earliest (Arthur 1998). Mount Hood hosted the National Downhill and Slalom Championships in March 1939. The event drew the nation's best skiers. Dick Durrance, one of the most successful early American ski racers, lamented the poor snow conditions-another hint at the challenges the industry would face on Mount Hood.

The growth of winter sports brought new recreation elements into Mount Hood's landscape. Trees and brush were cleared for the ski slopes. Wooden structures for the toboggan runs, warming and lunch shacks, and equipment rental shacks added a new dimension to development on the mountain. But while these elements indicated a new value placed on the forest, they were at first incorporated only to the extent that they would not interfere with traditional uses. When recreationists approached the Forest Service about a new jump at Multorpor, the agency required that a site be chosen that would not disturb a significant amount of timber.(Grauer 1975). As winter sports grew in popularity, these relatively modest developments would evolve into a much larger and more sophisticated recreation infrastructure, and would eclipse traditional uses of Mount Hood's landscapes. 


\section{Timberline}

The completion of the loop road brought more people to the mountain, and the Forest Service and tourism boosters identified the need for more facilities and greater lodging capacity. The Forest Service had built campgrounds and leased cabin sites as part of its effort to put off the lingering threat posed by the Park Service. But as winter recreation grew, there was a greater need for four-season accommodations and restaurants. Efforts to expand or replace Cloud Cap Inn were withering on the vine and Government Camp was becoming the "established commercial center, no matter how ugly and inadequate" (Weir 1977: 38). There were only two hotels and a handful of restaurants; on tournament days and during the annual winter carnival, the village was filled beyond capacity. Increasing Mount Hood's potential as a recognized tourism destination had become a priority, but Government Camp was six miles away from the timberline region where Olmsted's committee felt the greatest appreciation of the mountain was to be had, and at 3,800 feet, had inconsistent snow. A cabin built in 1916 near timberline on the Sand Canyon had sheltered climbers and skiers who made the long trip from snowline before the road was open in winter, but this was too small and primitive to be a proper hotel.

The Cascade Development Corporation's proposal for Cloud Cap Inn and the cableway died quietly in1931, but debate over the plan and the Department of Agriculture's approval broke the ice for commercial recreation development on the mountain (Weir 1977). This was an important year in the effort to build a hotel at timberline on the south side. A road from Government Camp to Camp Blossom at the 
head of Still Creek was completed - a vast improvement over the boulder-strewn wagon road with $25 \%$ grades that preceded it. Also in that year, Portland businessman and Chamber of Commerce member Berger Underdahl organized the Portland Winter Sports Association. The organization's creation was an indication of the critical mass recreation had gained on Mount Hood - a significant factor in securing funds for Timberline Lodge in the future. Its members, which included many of the usual names in Portland's business establishment, pressed the Forest Service for a timberline hotel on the south side, and Underdahl submitted the first formal proposal in 1934. His proposal was roundly dismissed by the agency, but it helped to set in motion the movement for a hotel at timberline on the south side.

Early in 1935 Emerson Griffith, a Portland shipping executive, enlisted the services of architect John Yeon (who had earlier submitted an alternative design for Cascade's Cloud Cap plan) to design a hotel for the timberline area on the south side. The modern building would have been located on the brink of the Salmon River Canyon about 1,000 feet east of Timberline's eventual location, but Griffith was of modest means, and being an outsider to the tight-knit circle of Portland's business and civic leaders, was not able to raise the funds for such a project in the middle of the Depression. But he was well connected in Washington, DC, where he had established a network as a newspaper reporter two decades earlier, and had been appointed Oregon administrator for the Federal Housing Administration in January. He was well respected for his ambition, efficiency, and organization skills, and in May was hand 
selected to be Oregon director of the recently created Works Progress Administration (WPA). The fortuitous timing was his and other hotel boosters' break.

Griffith wasted no time in applying for WPA funds for a hotel on Mount Hood. The WPA was in its infancy and was not an orderly, well-planned agency. "Projects were approved and begun, often with no firm sense of how to proceed in their work. . . Griffith was forced by necessity to adapt the same ad hoc methods in his administration of the project" (Weir 1977: vii). On September 7 he sent a one-page letter requesting a quarter-million-dollar grant, and the pieces fell quickly into place. The Forest Service would not operate the hotel but agreed to sponsor the project. The Mount Hood Development Association (MHDA), another Portland booster organization, formed with the goals of raising matching funds and eventually taking over as operator.

The arrangement could not have suited MHDA better. Financial problems had doomed hotel plans at Cloud Cap, and the Forest Service's primary concern with new proposals was the financial ability to follow through with a project. In this case, "MHDA would use federal relief funds rather than their own capital to build the hotel and, after it was finished, they would take charge of the facility as managers, and run it as a commercial profit-making enterprise" (Weir 1977: 69). From the WPA's perspective, it was an ideal combination of work relief project and recreation development that would provide public access to scenic amenities. The hotel had the enthusiastic support of national director Harry Hopkins, who approved it in December. 
John Yeon's design from several years earlier was initially considered for the hotel, but the MHDA wanted something closer to the great rustic National Park lodges of the era. The Forest Service Washington office appointed Gilbert Stanley Underwood, designer of many of the park projects, as architect for the projectperhaps something of a coup for the Forest Service given Underwood's close personal relationship with Park Service director Stephen Mather. Meanwhile, the Portland office appointed one of its own architects, W.L. Turner, to lead the project.

Underwood and Turner had very different ideas for the lodge's design. Underwood favored a more rustic approach similar to the National Park model that avoided any feeling of sophistication. Turner, on the other hand, felt a more "Stately Picturesque" design, like those of refined country estates of the era, was more appropriate. Underwood's basic design prevailed, but with several substantial changes by Turner. Most significantly was the basic configuration of the building. Underwood placed the main entrance and parking area on the north side of the lodge, between the building and the mountain. Turner suggested moving this area to the south side to avoid distracting from the scenery. Underwood also designed the two main wings of the building to meet at a 90-degree angle with the apex facing southeast. Turner predicted this would likely result in a "catch basin" for wind blown snow, and advised an angle of 120 degrees with the apex oriented to the northwest to deflect prevailing winds. They negotiated countless other details, but despite their differences, the men collaborated relatively amiably and a working set of plans was ready in April 1936. 
Crews worked through as much as 18 feet of snow to survey the site in May. The original plans for the new lodge placed it in the same location as Griffith's earlier proposal, but dangerous cornices on the edge of the Salmon River Canyon convinced engineers to move the lodge 1,000 feet to the west. Construction started in June, before final architectural plans were approved, and progressed rapidly. Winter arrived late in 1936, and the whole building was framed and roofed before the first snowfall. The lodge was not complete when President Roosevelt dedicated it on September 28, 1937, but the exterior was done and several rooms were hastily finished for their arrival. The building was completed later that fall, but by January 1938 the Forest Service had not received any acceptable bids for the operation of the hotel. Once again, Portland's civic and business communities intervened to further recreation on the mountain. The Mount Hood Development Association organized and incorporated Timberline Lodge, Inc., to run the operation. Timberline was opened to the public on February 4, with a grand ceremony at which Portland's recreation benefactors celebrated their crowning achievement.

Not everybody was completely enamored with the progress the lodge represented. The "sentimental objections" of climbers that Olmsted had discounted resurfaced. "Highways and trails have opened [mountain recreation centers] to the easy access of thousands. Some old timers see these changes with regret. They would keep the peak for those who have strength and courage to face the difficulties attending its approach" (McNeil 1990). 
Timberline's architectural style was not only distinctly northwestern, but also distinctly American. "America has never developed any highland architecture such as the Alpine of Europe. So an attempt was made to establish a distinctive style, which subsequently was given the name of Cascadian architecture. With steep sloping roofs, massive and rugged walls to meet the weight of the snows and force of the winds, the design was the development of a pioneer motif' (Griffith n.d. in Griffin 1978). With the pioneer motif, Native American themes and designs, and the use of local materials and craftsmen for the interior, Timberline Lodge was a "regional expression" (Gohs 1973:18).

By the beginning of World War II, the foundation of Mount Hood's recreation and tourism geography had been established. With the loop road, the basic transportation network had been largely formed, and the south side of the mountain emerged as the commercial center. Improved access along with other trends in society democratized recreation and tourism. Winter sports went from being a novelty act performed by working-class immigrants to a pastime in which many Portland residents-albeit the wealthier ones-could participate. With the design and construction of Timberline Lodge, a distinctive style of American mountain architecture was asserted in the landscape. The developments and conflicts on the mountain during this period took place in the larger context of the evolution of national public lands and recreation policy. As would be expected, events on the mountain were influenced by this broader story. The designation of the Mount Hood Recreation Area and the Mount Hood 
Primitive Area, which defined the general spatial distribution and intensity of development of recreation and tourism, reflect changes in Forest Service policy from its inception. The cableway controversy, which fell between these two designations, was the local conflict that brought many of these issues to a head on Mount Hood. The conflict was also an example of one in which local interests triumphed over national interests. Portland interests were directly involved in advancing and implementing most of the initiatives undertaken during this era, from the creation of the Bull Run Reserve to securing WPA funds for Timberline Lodge. For the boosters, recreation and tourism development on their mountain was a matter of pride as well as a boon to the bottom line. 


\section{Recreation and Tourism after World War II:}

$$
1940-1996
$$

\section{Dark days on the south side}

World War II brought to a halt what in many ways was the heyday of recreation and tourism on Mount Hood. Mount Hood had the most skiers of any area in the country during Timberline Lodge's first winter, and was poised to grow from there. European prestige represented by Otto Lang's ski school lent legitimacy to the mountain as a prominent winter recreation destination even after he left. The Magic Mile, the second ski lift in the world was opened in fall of 1939. Norway's Crown Prince Olav and Princess Martha dedicated the lift, screwing in the golden anchor bolt on one of the lift towers. The operators of Timberline tried to keep the lodge and ski area open after the United States entered World War II, but visitation dropped by half by the summer of 1942. The decision to close the lodge was made in the fall. And so went recreation and tourism on Mount Hood - and the rest of the country-until after the war.

Recreation resumed quickly when the troops came home Ski schools started up again the week before Thanksgiving 1945, and Timberline Lodge re-opened in December. But recreationists struggled to renew the industry's momentum of the previous decade. After several years of delay, the Skiway, a tram that ran from Government Camp to Timberline Lodge, opened in January 1951 as the second aerial tram in the country. The lift used logging technology to hook old city buses to a cable for the three-mile trip. Passengers could expect a rough ride and were not always 
guaranteed to reach the terminus on the first try. On occasion, the tram had to be backed down and re-started. The jury-rigged contraption seemed almost destined to be a temporary fixture in the landscape, and the opening of an improved road to Timberline in 1949 before the lift was complete helped to assure this fate. The Skiway was closed after just two years. In 1962 the towers were removed, leaving what would become the Thunderhead Lodge in Government Camp and a straight-line right-of-way through the forest, made more conspicuous by winter snow, as the only evidence of the experiment in the landscape.

The war may have tripped up Timberline just as it hit its stride, but the lodge had been running a deficit for its first few years of operation before the war. After it reopened in December 1945, it was plagued by neglect, abuse, and poor management. Day-to-day management changed several times, and in 1952 Timberline Lodge, Inc. sold the business. It was sold again the next year after a falling out between the new business partners, and the hotel fell far from its lofty New Deal ideals when gambling and prostitution turned up. In February 1955 the electric company shut off power to the building for failure to pay the bills and the IRS locked the doors (Grauer 1975, Rose 1986).

These were dark days on Mount Hood. The Battle Axe Inn had burned in 1950, and in the same month that Timberline closed, the Mountain View Inn also burned to the ground, leaving Government Camp with only one small motel. With almost no south side accommodations, tourism on Mount Hood suddenly lost its momentum that winter. Timberline opened again the following fall, but Government Camp's woes 
were compounded in 1958 when, as Olmsted's committee recommended almost 30 years before, Highway 26 was rerouted to bypass the core of the village. The new route was part of the same project that eliminated dangerous curves on Laurel Hill and improved the movement of through-traffic to points east. The re-alignment was also intended to accommodate the growing number of skiers in Government Camp. Presumably, skiers would still visit the businesses in the village, but these businesses also relied on travelers and tourists passing through. When the road passed them by, business in the village dropped by 40 percent. These events would contribute to economic stagnation and physical deterioration in Government Camp for decades to come (Clackamas County 1989). Compounding the village's woes, the upgraded highway provided easier access to Bachelor Butte when the new ski area opened near Bend in the winter of 1958-59. Although Bachelor was a farther drive for Portlanders, "skiers [had] already discovered the advanced slopes and the powder snow" by 1963 (Oregonian 1/6/63).

Timberline Lodge was closed only a few months before Richard Kohnstamm, a transplanted social worker from New York, took over the operation in April. Kohnstamm inherited the results of previous years' neglect: broken windows stuffed with hand-woven draperies, hand-made furniture destroyed for use as firewood, the bull-wheel for the Magic Mile chairlift broken in pieces on the floor of the lift-house, and over a thousand fire code violations. He cleaned up the building and built a new lift on sheltered slopes below the lodge in time to open again in December 1955. 
The RLK Company invested over a half million dollars and made a number of improvements over the next several years, but Kohnstamm's most significant contribution to the mountain's economy came in 1956 with the opening of the summer race camp on the snowfield of Palmer Glacier (Arthur 1998). The additional business during the summer would help to counter the other problems faced by Government Camp. This addressed an issue many ski areas would face in later decades. It also introduced new recreation elements to the highest point on the mountain and would be the focus of future debate on the limit of development on the mountain.

\section{Modest north side growth}

When Timberline opened, "the enthusiasm of the Portland men was balanced on the east side of the mountain by the disgruntled rumbling from their counterparts in Hood River. After all, an editorial complained, had not Cloud Cap Inn been recognized as the tourist hotel for the past fifty years. And also, was not the north side far more scenic than the south? Nevertheless, the article continues, Portland was listened to by the government because it had the larger population" (Lowe 1975). The north side had been eclipsed as the recreation and tourism center on Mount Hood by the time World War II started. But a good portion of the population in the Hood River Valley continued to recreate on the mountain and they proceeded with modest developments of their own.

Cloud Cap Inn was quickly becoming a relict of an era when "recreation spots were measured within a radius of a horse and wagon trip" (Oregon Journal 5/29/55). 
It had had a number of operators since the cableway proposal died, but enjoyed little success since the early years of the century. The inn was closed for the war, and the Forest Service bought the building in 1942. The agency considered tearing it down in 1950 when it could not find an operator. The Crag Rats, a Hood River climbing club, successfully lobbied the government to allow them to operate and maintain the building as the base for their snow survey and mountain rescue operations. The club repaired damage from years of neglect and vandalism, and continues to use Cloud Cap as a clubhouse today.

Winter recreation resumed quickly after the war. The loop highway was not plowed during the winter at this time so access to the south side ski areas was still difficult for Valley residents. Although they sometimes entered south side competitions, north side skiers wanting more terrain and amenities had to improve the modest ski developments that dated from the pre-Timberline Lodge era. The Hood River Ski Club revived the tow at Cooper Spur in the winter of 1945-46. They cleared more of the ski run and built a warming hut at the bottom in 1949. With no booster club investment or government funding, local club members did the work themselves, using farm equipment to pull stumps, level the slope, and haul lumber. In 1956 a loop road was built from the main highway to the ski area. In an arrangement with the Forest Service that reveals an agency not yet completely under the spotlight of public scrutiny, a local resident built the road in exchange for logs felled for the project. The Cooper Spur area was also the departure point for the Cloud Cap-Tilly Jane district, either on the Cloud Cap Road or on the Tilly Jane Trail. Climbing and 
hiking remained popular on both sides of the mountain in the post-war years. An American Legion post from Hood River had started to lead annual climbs from Cooper Spur in the 1920s, and by the late 1940s and early ' 50 s participants in the preclimb revelry and the climbs themselves numbered in the thousands (Grauer 1975). Although these forms of dispersed recreation had detrimental physical impacts such as erosion and trampling of vegetation (particularly as enjoyed but such large groups), they left little in the way of material culture in the landscape. The American Legion camp not far from Cloud Cap included a cookhouse and a small amphitheater. The Forest Service built a guard station in the Tilly Jane camping area in 1931 and the Tilly Jane Ski Cabin behind the American Legion camp in 1939. Used mostly by the ski and climbing clubs after the war, these structures were the extent of development at timberline on the north side.

Interest in recreation development was still very much alive on the north side, and support for building the Lolo Pass Road had quietly persisted for several decades. The campaign to open the pass was renewed in earnest in the early 1950 s when a road was built to allow access for the construction of the Bonneville Power Administration's transmission line from the Columbia River to the Sandy River basin. The road was complete in 1952 and the lines in 1953, and advocates of the road exerted greater pressure on the city of Portland and the Forest Service. The Hood River Chamber of Commerce arranged a public tour of the road in October 1954, and when the Forest Service unlocked the gates blocking the road, a caravan of 118 cars passed through. 
The Portland City Council, which still had veto power over land use in the Bull Run Reserve, voted to open the road to the public the following summer, acknowledging the public demand for access. The "link represent[s] the true completion of the Mount Hood Loop Highway. It provides a fast, scenic route to Hood River and Lost Lake and reveals closely the full sweep of the Mount Hood's western face with its great glaciers and alpine parks" (Oregon Journal 6/24/55). The reserve boundary would not be adjusted for several more years, but residents of the Hood River valley immediately seized the opportunity the road presented. In July another caravan was arranged by Portland and Clackamas and Hood River County interests to promote awareness and interest in the road. This time over 1,000 cars traveled the seven miles of closed road, and the Hood River Chamber of Commerce sponsored a luncheon at a restaurant in Hood River. When the pass opened the following year on July 1, a Hood River booster club gave travelers souvenier gifts of cherries, fishing lures, and pictorial maps of the Hood River Valley.

Hood River's gift of cherries reflects the growing efforts to capitalize on the tourism appeal of agriculture in the valley. By 1928, a few years after Parkdale residents had cleared the recently completed loop highway for visitors to their strawberry festival, as many as five thousand tourists were coming to enjoy the spring blossoms (Oregonian 5/7/28). In the early years, news of the blossoms' peak spread by word of mouth, and with the exception of the elaborate 1912 celebration, there were no formal events to mark the occasion. Local residents hosted family and friends, enjoying spring picnics throughout the valley. In the mid-1950s valley residents 
became more organized. The Pine Grove Grange spread the word when the time was near, and arranged a community dinner open to all on Blossom Sunday. In time the Blossom Festival would become a three-day affair, with information booths and coffee stands, a festival queen, another dinner at the Parkdale Grange, a pancake breakfast at the Westside Firehouse, and arts and craft bazaars.

\section{A new north side ski area}

As skiing's popularity increased and equipment improvements allowed for greater performance, north side skiers began to yearn for a bigger and better area on their side of the mountain. Cooper Spur was a small area with just two rope tows and a few runs, and it was not particularly challenging. Local racers had an advantage on the flat bottom section over other skiers who were used to steeper terrain (Grauer 1975). The ski area's biggest drawback was inconsistent snow. The top of the area was just 4,500 feet in elevation, and high freezing levels brought mid-winter rains that could quickly wash away a season's snow accumulation. Many valley residents made the long trip around the mountain to ski on the south side. "We used to ski at Timberline. We were tired of making the drive through Troutdale every time we went skiing" (Oregonian 1/21/93). It was also generally believed that the snow on the east and north sides of the mountain was drier and lighter than in the Government Camp area.

As members of the Hood River Ski Club made improvements to the Cooper Spur area in the mid-1950s, two local businessmen were planning a new area nearby. In 1955 a paper salesman from The Dalles and an orchard operator who was president 
of the Hood River Chamber of Commerce proposed a chairlift from near Inspiration Point up to the Cloud Cap Inn. Their project included three trails, a warming hut, and a lodge with dormitory accommodations for up to 200 guests. Perhaps they were not able to raise the funds for the project or could not resolve questions of who would improve and maintain the access road, but the proposal died with not another mention of it made after the initial coverage in Portland newspapers.

Hood River Valley residents with interests in a new ski area became better organized in the next few years. An unofficial "ski area committee" of the Hood River Chamber of Commerce searched for a new area to develop. One of their primary goals was to find a site that was "relatively unaffected by the lack of snow that plagues other areas." One member of the search committee stated a common sentiment on the north side: "We long have believed that the north side of the mountain has been neglected for recreation development" (Oregon Journal 8/29/61).

In August 1961 they announced a plan to develop a new area in the Elk CoveWy'East Basin area that included a lift to near Dollar Lake, two rope tows, and a lodge. This project faced nearly insurmountable odds from the outset. A significant portion of this development would be in the Mount Hood Wild Area (the new name given to the primitive area in 1940), and a re-classification of the land would be required by the Secretary of Agriculture for development to proceed. Such an action was considered highly unlikely - the Forest Service was concerned with setting a precedent for other wilderness areas around the country. But the Mount Hood National 
Forest supervisor supported the development of a new ski area on the north side and suggested that proponents find an area outside the wild area.

In spring 1962 the Hood River ski advocates stepped up their efforts, incorporating as Hood River Meadows Ski, Inc. for the purpose of "finding, developing and promoting a major ski area on the Hood River side of Mount Hood" (Hood River News 3/8/62). Although the company was intended to be a profit-making enterprise, it was "basically civil-spirited in nature" (Hood River News 10/18/62).

After a year of conducting surveys of snow, topography, and weather in various areas on the east and north sides of the mountain, the group identified the slopes above Umbrella Falls near the Hood River Meadows as the area with the greatest potential for skiing. They first brought their proposal to the Forest Service in fall of 1962 , and raised $\$ 3,500$ to help pay for a feasibility study conducted by the agency. Forest Service staff and others inspected and skied the area by helicopter to assess the area's potential, and the agency agreed that the area was ideal because of its consistent and dry snow, mild weather, vertical drop of 2,500 to 3,000 feet, and minimum of work required in clearing trails of stumps and rocks. The chief of the Forest Service approved the study, and in August 1965 the agency released an operator's prospectus and call for bids for the development of a 1,380-acre ski area.

The Forest Service received just two bids for the project: one from Hood River Meadows Ski, Inc., and the other from a Portland group called Mount Hood Meadows, Oregon, Ltd., headed by Franklin Drake. The prospectus was very specific about the ski facilities to be provided, so the two plans were similar. Both groups anticipated 
future summer operations that would include tennis courts and swimming pools and accommodate hikers and sightseers. The Forest Service awarded the bid to the Portland group in April 1966, reasoning that their proposal would better provide "immediate and long range benefits for the using public." When pressed later by Hood River interests, the agency cited inadequate drainage and sanitation facilities and questions about financing as critical factors that worked against their proposal.

Not surprisingly, the Hood River group felt snubbed. The headline on the front page of the Hood River News the day after the announcement declared the decision "a bombshell" (4/28/66). "To say the initial reaction was one of shock and bitterness would be to deal in understatement" an editorial the following week observed. One member of the Hood River group said, "Had it been left to the Forest Service from the first, we believe, there would be no development at all." An editorial in a Portland newspaper tried to offer some solace: "[T]hey at least have the consolation that their initiative is resulting in construction, just 35 miles from their city, of a ski area that will be the equal of any now on the mountain" (Hood River News 4/30/66). And some skiers involved in the bid were consoled: "T'm happy because we accomplished what we wanted to accomplish," one member said. "We got our ski area, even though not everyone in Hood River was happy" (Oregonian 1/21/93).

Consolation or none, what began as a plan for a local ski area would become Oregon's second largest ski area. The Forest Service issued Mount Hood Meadows, OR, Inc., a 30-year special use permit in July 1966 and work on the new area began soon after. The Forest Service built the two-mile road from the loop highway to the 
base area in summer 1966 and trees were cut for the new trails that fall. Construction continued the following spring, and in January 1968 Mount Meadows opened with nine trails, two chairlifts, a T-bar, and a base lodge. Vancouver, Washington, talent Gretchen Fraser, the first American to win Olympic gold in the winter games, skied through the ceremonial ribbon to officially to open the area.

Mount Hood Meadows was accessible only from the north that winter. The segment of the loop highway between Bennett Pass and the junction with Highway 26 was too narrow and curvy for highway crews to plow. The road was realigned and surfaced in summer 1968, and for the first time the Mount Hood Loop Highway was open year-round. Access from the south made for a slightly shorter trip from Portland to the new ski area, and the newly opened section considerably shortened the trip from the Hood River Valley to the south side ski areas. With this milestone in access on Mount Hood, the question of who owned the ski area became one mostly of local pride. "In long-range terms, it is hard to see that the county and Mid-Columbia will be materially hurt by the decision... There is some question that the ... ski area could be oriented any more toward the Mid-Columbia, even if the local bidders won" (Hood River News 5/5/66).

Animosity persisted, however, and the name of the proposed ski area caused additional consternation to some residents with deep roots in the valley. To them, this area where pioneers camped while fishing and berry picking had always been and should remain Hood River Meadows. "Hood River Meadows is a very real vivid memory to many very much alive people - it is not a commercial name picked to pull 
tourists to a man-made building. Hood River Meadows is as much a part of history as the mountain and river it got its name from and has been there just as long," opined one letter to the editor (Oregonian 10/7/67). The Oregon Geographic Names Board would recommend the place name be applied to all meadows on the drainage of Meadow Creek, and since the meadows and the ski area were separated by a ridge, the name Mount Hood Meadows could remain.

\section{Into the modern era}

Along with the rest of the country, Mount Hood had entered a new era in recreation and tourism development. Heightened awareness of environmental issues precipitated a wave of new legislation in the 1960s and 1970s, allowing environmentalists greater involvement in development projects and greater ability to fight them with litigation and administrative measures. The Multiple Use, Sustained Yield Act (MUSY), passed in 1960, required the Forest Service to give equal consideration to non-timber usesincluding recreation and fish and wildlife-in the management of national forests. The multiple use concept was expanded to include wilderness with the passage of the National Forest Management Act in 1976 (NFMA). This legislation also required the Forest Service to prepare management plans for each national forest. The National Environmental Protection Act of 1969 (NEPA) required all actions by federal agencies - including forest plans - to be assessed for environmental impacts. It assured for the first time public involvement through meetings and comment periods and allowed citizens to sue agencies that failed to follow the act's guidelines. 
Rather than the grand development schemes of the past, the new era was characterized by consolidation, mergers, and expansion and construction of new facilities at existing ski areas. There were no projects on the scale of the loop highway, the cableway, or Timberline Lodge. The smaller projects that were proposed revealed growing contention over recreation development on Mount Hood and invoked the powers given to citizens by new environmental laws.

The merger of Multorpor Mountain and Ski Bowl in 1964 was an early example of this trend. Shortly after the owners of Multorpor bought Ski Bowl, they cut trails to link the two areas and skiers could use both mountains on one ticket. As evidence that boosterism on Mount Hood was not dead, owner Carl Reynolds declared, "This area has all the potential for a ski complex equal to many European ski resorts" (Oregonian 3/5/64). Although this assessment might have been overly optimistic, the area would be recognized in a few years as the biggest and best night skiing area in the country. The combination of these two historical areas on Mount Hood was typical of the development activity that would follow, but it did not raise the objections of environmentalists that it might have if it had happened a few years later.

The new Mount Hood Meadows ski area was at the center of many conflicts of the new era. The most enduring, if not the most significant controversy in the decades that followed Mount Hood Meadows' opening was the resort's plan to create a yearround destination with overnight housing. From the beginning, the area's developers envisioned overnight accommodations on an 875-acre parcel of forestland it had 
purchased near Parkdale in the Upper Hood River Valley. Valley residents were wary of this type of development, which was much greater than what the Hood River contingent had planned, and immediately resisted (Willamette Week 9/12/77). At the heart of the ensuing conflict was the community's vision of itself and its relationship with the environment on Mount Hood's north side.

In 1977 Mount Hood Meadows sought a zoning change from the county planning commission that would re-classify 57 acres of its land for commercial use and allow construction of vacation condominiums. The county planning commission recommended denying the request, citing planning goals to maintain the upper valley as a resource production area in which housing was limited to farms and established areas. Poor road access, fire protection problems, and risk of "substantial change in the social and economic structure of the upper valley" were also factors considered in their decision (Oregonian 8/19/77).

The county commission disregarded the planners' findings and permitted the development later in the year. Valley residents who had voted for the land use plan that included minimal levels of development in the Upper Valley let their disapproval of the commission's decision be known the following year by voting out two of the four commissioners who voted for the zoning change. Parkdale residents favored the low growth development option, "which most voters saw as a rejection of Meadows' plan," by a margin greater than three-to-one (Willamette Week 12/15/81).

Opponents of the development, including 1,000 Friends of Oregon, four orchardists, and five current and former planning commissioners, appealed the 
decision to the newly created state Land Conservation and Development Commission (LCDC). The LCDC ruled that the county commission did not cite proper evidence in the administrative record to show how the project met state land use goals of protecting forest and farmland, and overturned the commissioners' decision in 1979. Feeling that the LCDC's action was based on a legal technicality rather than the merits of the project, Meadows tried again to develop the property in 1981. They requested a change to the county's comprehensive land-use plan in which 93 acres would be re-zoned from forest to residential. They cited 100 permanent, year-round jobs, as many as 45 short-term construction jobs, and $\$ 500,000$ in annual property tax revenues as benefits of their development to the community. The area's owners characterized opponents as "wealthy preservationists ... [who] want to lock up this valley and not let others come here to enjoy it" (Willamette Week 12/15/81).

The community for its part was less united in its opposition this time. Proponents in the valley saw an opportunity to diversify the economy at a time when the timber and orchard industries were being squeezed by national recession. One long-time fruit grower claimed, "Only the very best of orchards will continue in profitability. We cannot and must not continue to cling to these two old mainstays for support of our valley's economic destiny" (Oregonian 11/20/81). Opposition, however, remained strong, and concerns with the quality of the jobs created and the effect of tourism development on the cost of living were paramount. "What sense does it make to start inviting people in by the thousands, many of whom are willing to buy a part of the valley at prices few people here can afford?" questioned one life-long 
resident. Perhaps the greatest concern was the precedent the project would set for future development. Many valley residents feared that the required change to the landuse plan for this project would only make future changes for development easier, ultimately endangering the county's agriculture land base and way of life. Given that the development was proposed by Portlanders for Portlanders, it seemed obvious whom the growth would benefit under this plan (Willamette Week 12/15/81).

The Hood River County Planning Commission denied Meadows' request a second time. They decided that the company failed to prove that the land was not suitable for timber or agriculture and that the change in land-use designation would not meet a public need. The planning commission's decision again went to the county board of commissioners, but Meadows withdrew their application at the initial appeal hearing. The company wanted to enter more evidence into the record and hoped to avoid a repeat of LCDC's 1979 decision when the case was inevitably appealed again to the state level. The county commission decided Meadows had had ample opportunity to present all evidence; they denied the request and instead accepted their withdrawal of the application.

Having had no success with the development of housing on private land in the Hood River Valley, Mount Hood Meadows decided to pursue another option for overnight accommodations. The new plan would have repercussions reaching far beyond the quiet valley on the north side of Mount Hood. In late 1988 Meadows proposed an update to their master plan that included the construction of 2,000 units of overnight lodging, including a seven-story, 450-room hotel, on national forest land 
near the ski resort's base area. The project would far exceed any private development anywhere in the country on a national forest. Nearby Timberline Lodge, which loomed large in the hearts and imaginations of Oregonians, had only 59 units.

Despite the fact that the new proposal was on public land-or perhaps because of it-Hood River Valley residents resisted again. Opponents cited environmental impacts, particularly on fragile alpine meadows. Others opponents saw a project that would benefit primarily Portlanders: "There goes our wilderness mountain. I guess it's going to be a city mountain instead." Residents echoed a common refrain, lamenting the poor quality of jobs and the threat to the way of life in the valley. "It's such a lowpaying industry: It doesn't have anything for our children; it's hard to get excited about busing tables and working for tips" (Oregonian 4/16/89).

In May 1991 the Mount Hood National Forest approved 500 units of lodging along with a doubling of the ski area's capacity to 15,000 skiers per day and a 700acre expansion into the White River drainage. Opponents immediately appealed the decision to the Forest Service's regional office in Portland. In November the deputy regional forester decided that the MHNF's decision violated NEPA and ordered a closer examination of the area's cultural significance to Native Americans. The required ethnographic study was completed in two years but a revised environmental impact statement and record of decision for the development was delayed further. Meadows' general manager resigned in frustration before the resort abandoned plans for on-site resort housing in 1995. 


\section{Divergent paths}

By the time of Meadows' first lodging proposal in 1977, nascent land-use planning efforts sought to control growth and shape and direct new development on Mount Hood. These early plans echoed the 40-year-old sentiments of Olmsted's cableway committee in identifying Government Camp as the appropriate location for future overnight lodging and commercial development. The Mount Hood Community Plan, initiated by residents of the Hoodland corridor in 1970 and first adopted by Clackamas County in 1973, declared that "Due to its unique mountain location, it is the intent of the plan that Government Camp attain a development character of higher intensity that other village communities" in the corridor (CH2M Hill 1976:79).

The 1977 Mount Hood Planning Unit Proposed Interagency Plan took a broader view of the Mount Hood area by including the Upper Hood River Valley in its scope. This plan, elements of which were incorporated into both counties' subsequent comprehensive planning efforts, also designated Government Camp, along with Welches on the south side, for additional overnight housing and commercial facilities. It addressed specifically the issue of lodging at Mount Hood Meadows, stating that the option may be considered in the future if development on private lands on the south side fails to meet demand.

The Forest Service reiterated this stance in its Final Environmental Statement for Mount Hood Meadows master plan, released in March 1978. The agency would not consider any proposal "until Government Camp has been given sufficient lead time to see whether they can reasonably meet the public need." Any future 
development of overnight housing at the ski area must complement existing or potential development on private land. The Mount Hood National Forest Land and Resource Management Plan, which was prepared under NFMA and superseded the interagency plan, prohibited overnight accommodations except as permitted in future master plans. Although the agency approved overnight accommodations at Meadows in its 1991 EIS, the plan's appeal and subsequent abandonment left intact the concept of a mountain recreation center in Government Camp.

\section{Government Camp Revitalization}

Despite the prominent role given to Government Camp in the land use plans, by the 1980s it was still in a condition variously described as blighted, down at the heels, and run down. The community lacked purpose and identity, suggested one editorial (Oregonian 10/12/89). It was a story of missed opportunities, claimed the plan that was developed to reverse the village's decline (Clackamas County Development Agency 1989).

Clackamas County adopted the Government Camp Village Revitalization Plan in December 1989 to reverse the physical deterioration and economic stagnation that led to such descriptions. Declining property values, minimal growth, and reduced local investment prevented the village from financing its own improvements. This urban renewal plan would use public funds, in the form of tax increment financing, to pay for 34 specific projects to "improve the community's overall image and appearance, revitalize the village's retail core, diversity the area's recreational base, improve local 
access and circulation, and increase the availability of wintertime parking." Tax revenues resulting from increased assessed property values in the county after the plan's adoption would provide almost $\$ 10$ million over a fifteen-year period ending in 2005. Projects in the plan included sewer improvements, sidewalks and lighting, paving of residential streets, village welcome signs, recreational and cross-country ski trail improvements, retail site development, a nature center, and a museum and cultural center.

The revitalization plan was broadly supported. A group of residents, property owners, and business owners served as an advisory committee during the plan's development. Conservation organizations supported it, particularly as the preferred alternative to resort development on national forest land at Mount Hood Meadows. An Oregonian editorial observed, "The two plans inevitably conflict, and the one for Government Camp makes too much sense to ignore" (7/8/89).

Although the various plans for concentrating development at Government Camp were not entirely without dissent or opposition, by the 1990s they affirmed and advanced the south side's position as the recreation center. In contrast, during this time and in the decade after the Government Camp Revitalization Plan, the Upper Hood River Valley incorporated tourism in a way that preserved its history and re-asserted its identity as an agricultural community. 


\section{North side agri-tourism}

The Mount Hood Railroad had run between Parkdale and Hood River for decades, hauling fruit and timber from the upper reaches of the Hood River Valley to the Union Pacific mainline on the Columbia River. In the mid-1980s the pressure on resource industries that threatened the valley's way of life was brought to bear on the railroad. Two events in 1984 would threaten the railroad's existence and ultimately make it a symbol of change in the valley. First, Diamond Fruit Growers consolidated their operations in O'Dell and closed their Parkdale facility. Later in the year, Champion International closed its mill at Dee. This combination meant a drastic drop in freight on the line, particularly on its southern end. In 1987 the Union Pacific, which had owned the railroad since 1968, included it with 86 other branch lines to be divested.

Upper valley residents Jack Mills and Don McGraw started negotiations with Union Pacific to buy the five miles of track south of Dee in 1984. The railroad decided that to get that portion of the line they would have to buy all 22 miles. When the line went on the auction block in 1987, a group of local investors organized by Mills was one of six to bid on it. Although the Hood River group offered the lowest bid, UP felt they had the best business plan and accepted their offer of $\$ 650,000$. A disagreement over details of the contract threatened to kill the deal, but Mills and the new CEO of the UP had mutual acquaintances who convinced the executive to intervene on the group's behalf. In November 1987 the local consortium became owners of the Mount Hood Railroad (Mount Hood Railroad 1988). 
The group renewed passenger excursions on the line in 1988 and continued to ship freight until 1996 when the Dee Forest Products plant burned down. After this additional blow to the valley's resource economy, the train served primarily a tourism function. Its popularity grew, and special Christmas trains and Spirit of Oregon Dinner Train were added. Activity in Parkdale came in pulses with the train's arrival on summer days. The railroad connected not only Hood River with Parkdale, but also past with present.

In 1993 some members of the agricultural community sought another way to reconcile the valley's rural, resource-based past with the inevitability of contemporary tourism. A local merchant and the director of the Hood River Grower-Shipper Association established the Fruit Loop, a 45-mile self-led tour through the Hood River Valley's orchards. The eight or nine loosely affiliated growers and merchants who originally participated in the Loop aimed to boost sales as well as increase awareness among visitors of the agricultural way of life. In addition to selling their products, they offered tours, demonstrations, and tastings. The loop would grow to almost thirty participants and, with grant funds from the Oregon Department of Agriculture and Oregon Tourism department, produce almost 90,000 full-color visitor maps per year.

The Fruit Loop was integrated with and expanded upon the decades-old Blossom Festival tradition. There was little to it other than a concept and some maps. It consisted of an existing transportation network; aside from signs indicating the route, it brought little new development with it. It also capitalized on and promoted the development of niche markets in organic and gourmet products that would help to 
combat competition from foreign growers. Its popularity depended on and helped perpetuate the rural way of life by which many valley residents identified themselves and which they felt was threatened. It drew tourists to the valley in a way that allowed residents to maintain their rural heritage.

Upper valley residents affirmed more formally and explicitly their desire to maintain their rural heritage with the completion of the Community Action Plan for the Upper Hood River Valley in 1997. The plan was a result of federal efforts to help rural communities diversify their economies in light of declining timber harvests. The Northwest Economic Adjustment Initiative, companion to the 1993 Northwest Forest Plan, used existing government programs to provide financial and technical assistance to communities affected by the plan. The Forest Service awarded Hood River County a Rural Community Assistance grant in 1996 for the development of the action plan for Parkdale and Mount Hood.

The plan's vision statement for the upper valley declared the importance to the community of "a safe and friendly rural environment" in which "agriculture and forestry practices, along with recreation opportunities, thrive" (Upper Hood River Valley Action Team 1997). The action planning committee identified 13 goals that would help the community to achieve this vision. The goals included establishing a growth management strategy designed to maintain the low population density, the rural character, and the environmental qualities of the Upper Valley; protecting and enhancing agricultural practices so they continue to play an important role in the economy and lifestyles of the people living in the Upper Valley; maintaining the 
valley's 100 year-old reputation as a quality fruit growing district; and encouraging the management of recreation and tourism activities in ways that enhance, support, and recognize the traditional farm and forest land uses of the Upper Valley.

After completing a draft of the plan, the committee brought it to the community for review. Written comments received at an open house reiterated the community's feeling toward recreation and tourism, largely in response to the growth of wind surfing on the Columbia River. "Do not promote additional tourism, contain it." "Don't do anything to encourage tourism." "Just leave us alone! Just look at what you've done to Hood River with your tourism. You've ruined our small town.” "[R]ecreation and tourism do not in any way enhance, support, or recognize farm land use." "Parkdale does not need tourism to survive, it will create many more problems than benefits it would create." "Need to really encourage agriculture and timberthese are what will support the people in the area with livable incomes." "Leave everything as is, tourists can stay in Hood River" (UHRV Action Team 1997).

The Forest Service also awarded Clackamas County a number of Rural Community Assistance Grants. The difference in the way these grants, intended to bolster ailing rural economies, were applied in the two counties reinforces the divide in the social geographies and the degree of recreation and tourism development. On the south side, Clackamas County used the grants to fund various elements of the recreation-focused Government Camp revitalization plan. In contrast, Upper Hood River Valley residents used the money to clearly state their community's vision of itself as a rural community in which tourism was secondary to agriculture. 
While the basic framework of tourism and recreation on Mount Hood was established in the period before World War II, expansion, consolidation, and a general filling in of that framework characterized most new development after the war. Recreationists spent the relatively quiet post-war years catching back up to speed and trying to reclaim the glory of the $1930 \mathrm{~s}$. That glory was almost completely lost in the $50 \mathrm{~s}$ with the threatened razing of Timberline Lodge. But all was not lost. Timberline was saved and, under new management and in good time, prospered. The visions of the mountain's early boosters would not be realized-Government Camp's decline reflected unrealized dreams and expectations--but recreation, particularly skiing, grew steadily. The divide between the north and south sides also grew. Although Lolo Pass was opened to the public in 1955 , it never became a major thoroughfare. With the majority of Portlanders going to the south side to recreate, the north side was left in relative isolation, particularly in the winter. Tourism growth was much more limited there, and during these years, the Upper Hood River Valley started to emphasize forms of tourism that complemented rural ways of life.

Events at a national scale would again influence developments on Mount Hood. The 1960s were a time of national upheaval, and the opening of Mount Hood Meadows in 1967 was the most significant development on the mountain after World War II. The circumstances of its creation increased tensions between residents of the Hood River Valley and Portland. Meadows would become the second most visited ski area in Oregon at a time when the industry exploded across the country. It would also 
become the focal point of litigation spawned by the modern era's sweeping new environmental protection legislation. In the years after it opened, various plans by the ski area resulted in conflicts that characterized recreation development around the country. After years of piecemeal resistance to expansion projects, residents of the Upper Hood River Valley drafted an action plan that served as a formal statement of their rural identity. In its rejection of tourism, the plan succinctly articulated the geographic divide on Mount Hood. 


\section{Discussion}

The complementary concepts of location, place, and landscape provide a useful interpretive framework with which to explain how and why recreation and tourism have developed on one of Oregon's most recognized symbols in the last century.

\section{Location}

Changing national values of land and natural resources in the late nineteenth century led to the reservation of public lands on Mount Hood. Within this national context, though, local interests-largely recreationists-drove the creation of forest reserves. After efforts to create reserves at a local and state level failed, and then with the designation of the nation's largest forest reserve in 1893. The resulting base map of federal land ownership would shape the location, distribution, and pattern of recreation and tourism development on the mountain. The forest boundaries and private inholdings that would determine where and how intensively recreation development could occur started to take shape at this time.

In the early days of recreation on Mount Hood the mountain was truly, as described in a contemporary marketing campaign, "close to Portland but a world away." It was less than 50 miles as the crow flies from town to summit, but in those days "recreation spots were measured within a radius of a horse and wagon trip" and relatively few people made the arduous journey to the mountain. As technology 
improved, the world became smaller and, for practical purposes, the distance between Portland and Mount Hood shrank. Railroads brought early tourists to the first resort on the mountain by way of Hood River. In time, better roads made access to the mountain easier and automobiles helped to democratize recreation and tourism. With these improvements and its relatively gentle and accessible topography, Government Camp and the south side became the preferred destination. The north side, left in relative isolation for several decades, fully embraced its rural identity. Eventually, construction of the loop highway made possible the circumnavigation of the mountain in a day.

This trend of a shrinking and increasingly connected world resulted in a change in Mount Hood's role in the regional spatial network. McNeil's characterization of the mountain as a part of the city of Portland became more appropriate than "Close to home, a world away." As transportation improved, the distance to "a world away" grew. Like ski instructor Otto Lang, the attention of Portland's vacationing skiers was drawn to regions with more spectacular scenery and better snow, and Mount Hood became more of a day trip. Highway 26 became a main artery between the wet and dry sides of the Cascades, and the rerouting of the road around the core of Government Camp in the 1950s was symbolic of the village's place in the grand scheme. Many travelers on Highway 26 speed right past the village, not even realizing it is there, and Mount Hood's tourism industry has been left struggling to make a destination of itself. "When your community is a quick hour away from the state's largest metropolitan mecca, you're not a destination area. You never will be" (Oregonian 4/25/04). 
Place

The distinct geographic divide in the degree of recreation development between the north and south sides of Mount Hood can be explained not only by physical geography, ease of access, and land ownership patterns, but also by social geographies. Communities on each side of the mountain invested meaning in the places they called home and defined themselves differently.

On the north side, in the Upper Hood River Valley, a rural identity evolved in which a resource based economy became the foundation of the community. Timber and agriculture provided employment for many valley residents. Although the mountain's earliest tourist resort was located on the north side, later tourism was incorporated into the upper valley only to the degree to which it complemented the rural identity. In recent decades, the threat to their way of life has been a significant factor in local residents' opposition to various tourism development proposals. Tourism initiatives that have been embraced-the Blossom Festival, the Fruit Loop, and the Mount Hood Railroad—have incorporated and advanced the historical and agricultural aspects of valley life, and the Upper Hood River Valley maintains a rural character today.

In contrast, recreation and tourism have long been a central part of community identity on the south side of the mountain, particularly in Government Camp. Government Camp's earliest permanent residents staked claims to establish an early hostelry and guided its patrons to the summit. Figures in the early development of winter recreation and participants in various competitions made their living in the 
woods, but identified closely with the sport and helped advance its development. As recreation grew and more people from Portland traveled to the mountain, businesses along the loop highway in the Mount Hood Corridor catered primarily to recreationists and tourists. Although the village has been the recognized center of recreation on the mountain for decades by the 1990s it still was not committed to its development, and it still lacked cohesiveness of purpose and identity.

Almost any description of Northwesterners, and Portlanders in particular, in guidebooks or lifestyle magazines, depict a people with an affinity for the outdoors. Mount Hood has been Portland's playground almost from the time of the state's settlement, and recreation development on the mountain, particularly on the south side, is largely a reflection of the values, priorities, and tastes of the city's residents. While much of the forest in the Cascades-and in much of what would become the Mount Hood National Forest—-served primarily utilitarian purposes, recreation was established as the priority use for the immediate vicinity of the summit late in the nineteenth century. In the establishment of the Cascade Range Forest Reserve, the construction of the Mount Hood Loop Highway, and possibly the south side's official designation as a recreation area, Portlanders who valued the mountain's natural and recreation amenities were the driving force behind the events that shaped the basic spatial framework of development.

Portlanders were also behind almost every new development on the mountain, from Cloud Cap Inn to the cableway to Mount Hood Meadows. Instigated, designed, and built largely by Portlanders, Timberline Lodge became a symbol of the city and 
the region's identification with the outdoors, their pioneer heritage, and Native American legacy. As the popularity of outdoor recreation grew, different factions had different priorities. These conflicting visions of the mountain played out in conflicts over many projects. Confrontations over the cableway, the expansion of Mount Hood Meadows, and a number of other projects reflect tensions and contradictions characteristic of Portland.

Not all development on Mount Hood resulted from the active decisions or efforts of Portlanders. As the mountain became primarily a day-use area, development reflected the needs of visitors whose tastes led them to other places for vacations and who mostly passed through the Mount Hood area rather than staying overnight. The start of the decline of Government Camp coincides with improved access to the mountain. Increasingly, less direct interest and investment by Portlanders contributed to blighted condition that would plague the village for decades. The rest stop just east of the village is an appropriate symbol of this trend. One long-time resident estimated at the turn of the twenty-first century that as many as seventy percent of visitors stop only to use this facility.

\section{Landscape}

The first significant recreation element was incorporated into Mount Hood's landscape when Cloud Cap Inn was built on the north side in 1889. The inn was built of rock and silver fir and guyed to the side of the mountain with steel cables, its owners not entirely certain it would last through the first winter. In time, technological advances 
and changes in society would manifest themselves in the landscape, Cloud Cap would become a relict, and the south would become the recreation center of the mountain. But the old inn still stands, well into its second century. It turns out the Forest Service was its greatest threat, and today it is a symbol both of the enduring appeal of recreation on Mount Hood and of the ambivalence toward it.

With the construction of Oliver Yocum's hotel in Government Camp a decade later, recreation and tourism had established a physical presence on both sides of the mountain. The relative ease of travel still gave the north side an advantage in attracting tourists from Portland, and for several more years it remained the preferred destination. The Snowshoe Club, founded by some of Portland's most elite families, built their clubhouse only a stone's throw from Cloud Cap in 1910.

Not long after this, however, roads and automobiles started to improve, resulting in the shift in recreation to the south side. This shift was cemented when Multnomah County finally committed funds to surface the last leg of the loop highway in 1923. The new and improved road paved the way for thousands of Portland winter sports enthusiasts to flock to Government Camp to watch ski jumping competitions and play in the snow themselves. New recreation elements were incorporated into the landscape on both sides, but the rope tows, toboggan runs, ski jumps, and warming huts had a more dominant presence around Government Camp. At about the same time, cut over forestland in the Upper Hood River Valley was converted to orchards, and the first of the fruit trees that would become ubiquitous in the valley were planted. 
By the 1930s the seeds of contemporary cultural landscapes had taken root on both sides of the mountain, and the paths they took soon diverged. While thousands of visitors flocked to Government Camp to watch ski competitions, over 10,000 acres of orchards filled the valley on the north side. New hotels and businesses in Government Camp made clear the role of recreation there, while signs of tourism on the north side were much more subtle. The orchards became an attraction in their own right, and people came to see the blossoms and picnic in the valley each spring. The Mount Hood Railroad, primarily a freight hauler for upper valley fruit and timber, ran regular excursion trains, prompting scorn from local residents.

With the completion of Timberline Lodge in 1937, a single building simultaneously stated the dominance of recreation on Mount Hood and evoked the pioneer heritage and ethic that was normally manifest in timber camps and agricultural fields, Ironically, the lodge would have done little to satisfy the need for which it was originally envisioned. With only a few dozen rooms, it did little to alleviate a shortage of accommodations in a destination besieged by thousands of visitors. In the end, it would be a moot point.

World War II brought the heyday of recreation and tourism on Mount Hood to a halt, and the area would never fully recover the glory of those heady years. Post-war landscapes revealed an area trying to regain its footing in a rapidly changing world. The SkiWay, a jury-rigged alternative to a tram or gondola, was delayed for several years before opening and was shut down after just a few years of operation. The shuttering of Timberline in 1955 was perhaps recreation's low point on Mount Hood. 
The burning of several prominent hotels in Government Camp during that period and the rerouting of the loop highway around the village core in 1957 compounded the area's woes. These events marked the beginning of a period of decline that would result in Government Camp being described as blighted, down at the heels, and a missed opportunity.

Timberline quickly reopened and with the hard work of new management, regained its status as the pride of Mount Hood, but as transportation continued to improve, the mountain became more of a day area than a destination. Hotels in Government Camp that had burned were not re-built because the owners lacked insurance, but lack of interest must have contributed as well. The construction of the rest area just east of the village in 1964 was a significant symbol of visitors' perception of Government Camp.

The most significant development on the mountain after World War II grew from the desire of skiers in the Hood River Valley for a better area to serve the north side. The new Mount Hood Meadows ski area and the animosity it generated when the development bid was awarded to a group of Portland interests in 1966 ushered in a new era of recreation and tourism. Mergers, consolidation, and expansion of existing ski areas rather than substantial new development characterized this period. Environmental legislation of the 1960 s and 70 s that empowered opponents of projects helped to limit new development to the infill of the landscape's recreation infrastructure 
Development plans by Mount Hood Meadows with the greatest potential to transform Mount Hood's landscapes went largely unrealized. Expansion into the White River Canyon and proposals for overnight accommodations on national forest land at the base of the ski area and in the Upper Hood River Valley drew the ire of many local residents. These proposals and Meadows' environmental record galvanized resistance to recreation development on the north side. They instead incorporated tourism initiatives that affirmed their rural identity and did not appreciably alter the landscapes of the north side. The Fruit Loop and the Mount Hood Railroad were grounded in the valley's agricultural heritage and were subtle elements of tourism in the landscape that many visitors would not even recognize as such.

\section{Conclusion}

While the trend toward a dichotomy of big destination ski resorts and smaller areas that cater to a regional population base is an accurate description of the industry in general, like most generalizations it is only accurate up to a point. Some day areas are bigger than others, and a continuum in size and sophistication of ski areas, from 40acre Cooper Spur to 4,000-acre Whistler-Blackcomb, still exists. Mount Hood lies somewhere near the mid-point of this continuum. It is an area that has more appeal than most local or day-use recreation or tourism draws but is not as spectacular as the elite destinations that others have written about, such as Sun Valley, Vail, Aspen, or Whistler. Limitations of scenery, quality of snow, and other natural amenities place it in an intermediate category of recreation and tourism attraction. As would be 
expected, this status as an attraction of intermediate quality and appeal has determined the type of recreation and tourism to develop on the mountain.

Without a national or international constituency driving development, local and regional interests have exerted the greatest influence on Mount Hood. Local residents have had more success than those in many resort areas in shaping and controlling development in a way that meets their conceptions of the place in which they live. In the Upper Hood River Valley state land use law and the relative viability of orcharding have allowed residents to maintain a rural, agriculture-based way of life. They have been successful in resisting major recreation development in the valley and have been able to incorporate tourism into their lives and landscapes in a way that affirms their heritage.

Portland, however, undoubtedly exerts an overwhelming influence on recreation and tourism development on the mountain, suggesting that the post-modern colonialism model is relevant here, if only at a different scale than at major destination areas. But the fact that the mountain is essentially in Portland's backyard lends a significantly different complexion to the scene. In many ways, Mount Hood is like a city park- -one that has seen some neglect and abuse and is in need of some repair-where one is likely to run into a friend or colleague while out hiking, skiing, or snowshoeing. From this perspective, at a slightly smaller scale, development on the mountain is a local affair that is influenced little by outside interests.

While greater local and regional control over development has meant less of the transformation of communities and landscapes that has occurred at other resorts, it is 
largely the lack of outside interest that has contributed to the decline of Government Camp. Because the majority of people who recreate on the mountain return to Portland and the surrounding area to eat, sleep, and shop, there is less demand for the services typically found in destination areas. Declining property values, minimal growth, and reduced local investment prevented the village from financing its own improvements. Without market forces driving even modest improvements, government investment in the form of the revitalization plan has been necessary to reverse the village's stagnation.

This combination of local and metropolitan interests has left an imprint on Mount Hood that reflects tensions and contradictions that define Oregon in the early twenty-first century: past vs. future, old vs. new economies, urban vs. rural inclinations, progress vs. status quo, upscale vs. modest. Spatially, temporally, and ideologically, it straddles the divide between two visions: a heavily technology dependent, service based economy in the Willamette Valley and a traditional, resource-based economy in much of the rest of the state. Mount Hood reveals this collision between worldviews much more vividly than the contrived Alpine villages, Victorian mining towns, and Wild West towns where the reality of the post-modern transition is suppressed in favor of a glossy image presented and sold to consuming visitors. 


\section{Works Cited}

Abbott, C. 2000. Land for cities, scenery for city people. In Land in the American West: Private Claims and the Common Good, ed. W.G. Robbins and J.C. Foster. Seattle: University of Washington Press.

Abbott, C. 2003. Urbanism and environment in Portland's sense of place. Presented at President's Plenary Session, Association of Pacific Coast Geographers, September 2003, Portland, OR.

Abbott, C., S. Adler, and M. Post Abbott. 1997. Planning a New West: The Columbia River Gorge National Scenic Area. Corvallis: Oregon State University Press.

Arthur, J. 1998. Timberline and a Century of Skiing on Mount Hood. Whitefish, MT: Whitefish Editions.

Beck, C. 1986. Preserving western spaces: Frederick Law Olmsted's Landscape Planning Vision. B.A. Honors Thesis. Brown University, Department of History.

Bosker, G. 1986. Beginnings: The Uphill Movement. In Timberline Lodge: A Love Story, ed. J. Rose. Portland: Graphic Arts Center Publishing Company.

Burtchard, G.C. and R.W. Keeler. 1991. Mount Hood Cultural Resource Reevaluation Project: a consideration of prehistoric and historic land-use and cultural resource survey design reevaluation, Mount Hood National Forest, Oregon. Portland, OR: Laboratory of Archaeology and Anthropology, Department of Anthropology, Portland State University.

Clackamas County Development Agency. 1989. Government Camp Village Revitalization Plan. Clackamas, OR.

Clackamas County Planning Department. 1976. Mount Hood Community Plan. Oregon City.

Coleman, A.G. 2004. Ski Style: Sport and Culture in the Rockies. Lawrence: University Press of Kansas.

Deering, T.P., Jr. 1986. Mountain architecture: an alternative design proposal for the Wy'East Day Lodge, Mount Hood, Oregon. M.Arch. Thesis. University of Washington, Architecture. (http://www.seanet.com/ tdeering/thesis/toc.htm)

Giordano, S. 2004. Ski Guide: 2004-05. Mount Hood. Outside Online. URL: U.S. Department of Agriculture. Forest Service. Downloaded 6/13/05. 
Grauer, J. 1975. Mount Hood: A Complete History. Gresham, OR: Self published.

Griffin, R. and S. Munro. 1978. Timberline Lodge. Mount Hood, OR, Friends of Timberline.

Griffith, E.J. n.d. Timberline Lodge-An Experiment. Unpublished paper.

Harris, C. 2001. Archival Fieldwork. Geographical Review 91(1\&2): 328-334.

Harris, C. 1971. Theory and synthesis in historical geography. Canadian Geographer 15(3): 157-172.

Hood River News. Var. Dates. Hood River, OR.

Lane, R. 1996. Shakeout in Skiing. Forbes 157 (9): 56.

Loomis, J. 1993. Integrated Public Lands Management. New York: Columbia University Press.

Lowe, D. and R. Lowe. 1975. Mount Hood: Portrait of a Magnificent Mountain. Caldwell, ID: Caxton Printers.

McNeil, F.H. 1990. McNeil's Mount Hood, Wy'East: The Mountain, Revised edition. Zig Zag, OR: Zig Zag Papers.

Meinig, D.W. 1972. American Wests: Preface to a geographical interpretation. Annals of the Association of American Geographers 62: 159-84.

Meinig, D.W. 1978. The continuous shaping of America: a prospectus for geographers and historians. American Historical Review 83: 1186-1217.

U.S. Department of Agriculture. Forest Service. Mount Hood Interagency Planning Team. 1977. Mount Hood Planning Unit proposed interagency plan: final environmental statement. Portland, OR.

U.S. Department of Agriculture. Forest Service. 2004. National Visitor Use Monitoring Results: Mount Hood National Forest. Portland, OR

Mount Hood Railroad. 1988. Rider's guide to the Mount Hood Railroad: A companion for your trip from the city of Hood River, Oregon to the foothills of Mount Hood. Hood River, OR. 
Muir, J. 1875. Flood-storm in the Sierra. Overland Monthly 14 (June 1875): 496.

Nash, R. 1982. Wilderness and the American Mind. New Haven: Yale University. Press.

Olmsted, F.L., Jr. 1930. Public values of the Mount Hood area. Report prepared for USDA. 71 st Cong., 2d sess. Senate. Doc. 164

Oregon House of Representatives. 1929. House Joint Memorial No: 13, adopted $2 / 22 / 29$.

Oregonian. Var. Dates. Portland, OR.

Oregon Journal. Var. Dates. Portland, OR.

Pacific Northwest Ski Areas Association (PNSAA). 2004. Pacific Northwest Annual Visitation Data. Hood River, OR.

Palmer, J. 1994. A Sight So Nobly Grand: Joel Palmer on Mount Hood in 1845. Portland: Oregon Historical Society Press.

Pearce, D.G. 1979. Towards a geography of tourism. Annals of Tourism Research 6: 245-272.

Pope, C. L. 1992. Switchback to the timber: a history of the Mount Hood Railroad and the Oregon Lumber Company. Hood River, OR: Old Forester Pub. Co.

Portland Telegram. Var. Dates. Portland, OR.

Power, T.M. 1996. Lost Landscapes and Failed Economies. Washington: Island Press.

Rakestraw, L. 1955. A history of forest conservation in the Pacific Northwest, 18911913. $\mathrm{PhD}$ Dissertation. University of Washington.

Riebsame, W.E.; and J. Robb. 1997. Atlas of the New West: Portrait of a Changing Region. New York: Norton.

Rose, J., ed. 1986 Timberline Lodge: A Love Story. Portland: Graphic Arts Center Publishing Company.

Rothman, H. K. 1996. Selling the Meaning of Place: Entrepreneurship, Tourism, and Community Transformation in the Twentieth-Century American West. Pacific Historical Review 65(4): 525-557. 
Rothman, H. K. 1998a. Devil's Bargains: Tourism in the Twentieth Century American West. Lawrence: University Press of Kansas.

Rothman, H. K. 1998b. Tourism as Colonial Economy: The Distribution of Economic Power and the Significance of Place in Western Tourism. In Power and Place in the North American West, ed. J. Findlay and R. White, pp. 177-203. Seattle: University of Washington Press.

Runte, A. 1997. National Parks: The American Experience, 3e. Lincoln: University of Nebraska Press.

Russell, M.B. 1978. Our trip to Mount Hood, 1893. Oregon Historical Quarterly 79(2): 203-210.

Sleeth, P. 1996. Mount Hood National Forest. Oregonian poster insert.

Steen, H.K. 1976. The U.S. Forest Service: A History. Seattle: University of Washington Press.

Throop, E.G. 1995. Rustic architecture: period design in the Columbia River Gorge. Cultural Resource Management 18(5): 10-12.

Tompkins, J. 2004. "The final leg of the trail." The Road to Oregon. The End of the Oregon Trail Interpretive Center Web site: http://www.endoftheoregontrail.org/road2oregon/sa21barlowrd.html. Downloaded 9/13/04.

Tweed, W. C. 1989. A History of Outdoor Recreation Development in National Forests 1891-1942. Washington, D.C.: U.S. Department of Agriculture, Forest Service.

Upper Hood River Valley Action Team. 1997. Community Action Plan for the Upper Hood River Valley. White Salmon, WA: James H. Hulbert \& Associate.

U.S. Department of Agriculture. Forest Service. 1924. Mount Hood gains new fame: name of Oregon National Forest changed to Mount Hood (Press Release). Portland, OR.

Weir, J. 1977. Timberline Lodge: A WPA experiment in architecture and crafts. $\mathrm{PhD}$ Dissertation. University of Michigan, History of Art. 
Willamette Week. Var. Dates. Portland, OR.

Williams, G. W. 1998. The USDA Forest Service in the Pacific Northwest: Major Political and Social Controversies Between 1891-1945. Washington: USDA Forest Service.

Williams, M. 1994. The relations of environmental history and historical geography. Journal of Historical Geography 20(1): 3-21.

Wingle, H.P. 1994. Planning Considerations for Winter Sports Resort Development. Forest Service, USDA.

Wright, D. T. 1976. Recollections of Cloud Cap Inn. Oregon Historical Quarterly 77(1):61-66.

Wright, J.B. 1993. Rocky Mountain Divide: Selling and Saving the West. Austin: University of Texas Press.

Wyckoff, W. and L. Dilsaver. 1995. The Mountainous West: Explorations in Historical Geography. Lincoln: University of Nebraska Press.

Wyckoff, W. 1999. Creating Colorado: The Making of a Western American Landscape, 1860-1940. New Haven: Yale University Press. 


\section{Appendix A}

\section{Timeline of Recreation and Tourism Development on Mount Hood, Oregon}

1845 Samuel Barlow cuts road across south side of the mountain

1857 First confirmed climb

1889 Cloud Cap Inn opens

1893 Cascade Range Forest Reserve designated

1894 Mazamas founded on summit

1915 First proposal for National Park

1924 Mount Hood National Forest established (from Oregon National Forest)

1925 Mount Hood Loop Highway opens

1926 Mount Hood Recreational Area

1926 Cableway to summit proposed

1927 Road to Government Camp opens in winter

1928 Multorpor opens with jump hill

1931 Mount Hood Primitive Area designated

1937 Ski Bowl opens

1937. Timberline Lodge opens

1945 Cooper Spur opens

1954 First Blossom Festival in Hood River Valley

1967 Mount Hood Meadows opens

1988 Mount Hood Railroad opens for tourists

1992 Northwest Forest Plan/Northwest Economic Adjustment Initiative

1993 Fruit Loop established in Hood River County

1996 Community Action Plan for the Upper Hood River Valley

2001 Cooper Spur expansion proposed 